\title{
Hebei loess section in the Anyemaqen Mountains, northeast Tibetan Plateau: a high-
} resolution luminescence chronology

Chongyi, E.; Sohbati, Reza; Murray, Andrew Sean; Buylaert, Jan-Pieter; Liu, Xiangjun; Yang, Long; Yuan, Jie; Yan, Wenting

\section{Published in:}

Boreas

Link to article, DOI:

10.1111/bor.12321

Publication date:

2018

Document Version

Peer reviewed version

Link back to DTU Orbit

Citation (APA):

Chongyi, E., Sohbati, R., Murray, A. S., Buylaert, J-P., Liu, X., Yang, L., Yuan, J., \& Yan, W. (2018). Hebei loess section in the Anyemaqen Mountains, northeast Tibetan Plateau: a high-resolution luminescence chronology. Boreas, 47(4), 1170-1183. https://doi.org/10.1111/bor.12321

\section{General rights}

Copyright and moral rights for the publications made accessible in the public portal are retained by the authors and/or other copyright owners and it is a condition of accessing publications that users recognise and abide by the legal requirements associated with these rights.

- Users may download and print one copy of any publication from the public portal for the purpose of private study or research.

- You may not further distribute the material or use it for any profit-making activity or commercial gain

- You may freely distribute the URL identifying the publication in the public portal 




\section{Hebei loess section in the Anyemaqen Mountains, northeast Tibetan Plateau: a high-resolution luminescence chronology}

\begin{tabular}{|c|c|}
\hline Journal: & Boreas \\
\hline Manuscript ID & BOR-056-2017.R2 \\
\hline Manuscript Type: & Original Article \\
\hline Date Submitted by the Author: & 12-Apr-2018 \\
\hline Complete List of Authors: & $\begin{array}{l}\text { E, ChongYi; Qinghai Normal University, Key Laboratory of Physical } \\
\text { Geography and Environmental Processes of Qinghai Province; Nordic } \\
\text { Laboratory for Luminescence Dating, Department of Geoscience, Aarhus } \\
\text { University } \\
\text { Sohbati , Reza ; Nordic Laboratory for Luminescence Dating, Department } \\
\text { of Geoscience, Aarhus University; Technical University of Denmark, Center } \\
\text { for Nuclear Technologies } \\
\text { Murray, Andrew; Aarhus University, Department of Geosciences } \\
\text { Buylaert, Jan-Pieter; Nordic Laboratory for Luminescence Dating, } \\
\text { Department of Geoscience, Aarhus University; Center for Nuclear } \\
\text { Technologies, Technical University of Denmark, } \\
\text { Liu, Xiangjun; Qinghai Institute of Salt Lakes, Chinese Academy of } \\
\text { Sciences } \\
\text { Yan, Wenting; Qinghai Normal University, Key Laboratory of Physical } \\
\text { Geography and Environmental Processes of Qinghai Province } \\
\text { Yuan, Jie; Qinghai Normal University, Key Laboratory of Physical } \\
\text { Geography and Environmental Processes of Qinghai Province } \\
\text { Yang, Long; Qinghai Normal University, Key Laboratory of Physical } \\
\text { Geography and Environmental Processes of Qinghai Province }\end{array}$ \\
\hline Keywords: & loess, Tibetan Plateau, luminescence dating, quartz and K-feldspar \\
\hline
\end{tabular}


Hebei loess section in the Anyemaqen Mountains, northeast Tibetan Plateau: a high-resolution luminescence chronology CHONGYI E, REZA SOHBATI, ANDREW S. MURRAY, JAN-PIETER BUYLAERT, XIANGJUN LIU, LONG YANG, JIE YUAN AND WENTING YAN

\author{
E, C., Sohbati, R., Murray, A. S., Buylaert, J.-P., Liu, X., Yang, L., Yuan, J.\& Yan, W.: \\ Hebei loess section in the Anyemaqen Mountains, northeast Tibetan Plateau: a \\ high-resolution luminescence chronology. Boreas...
}

The extensive aeolian deposits of the Tibetan Plateau represent important environmental archives, recording information about the past interplay between the Asian monsoon and Westerlies and the link between dust accumulation and Quaternary glaciations. In northeast Tibetan Plateau, mantles of sandy loess form a distinct belt lying between 3500 and $4500 \mathrm{~m}$ a.s.I. on the east-facing slopes of the Anyemaqen Mountains. However, there is little chronological information about the loess deposits in this region. This study provides a detailed chronology for loess formation in the region using luminescence dating. A total of 29 samples were collected from an 8-m thick homogeneous loess section at Hebei (HB) for dating sand-sized (63-90 $\mu \mathrm{m})$ quartz and K-feldspar fractions using optically stimulated luminescence (OSL) and infrared stimulated luminescence (IRSL and pIRIR) signals, respectively. The resulting quartz and feldspar ages are in good agreement over the last 40 ka; beyond this (i.e., $D_{e}>120 \mathrm{~Gy}$ ), the quartz age is underestimated, and the pIRIR 170 feldspar ages are considered more reliable. The HB loess section records continuous environmental information from $\sim 50$ to $\sim 30 \mathrm{ka}$, i.e. throughout Marin Isotope Stage (MIS) 3. Mass accumulation rates (MAR) varied considerably over this period with increased dust accumulation around $\sim 38 \mathrm{ka}$ and after $\sim 32 \mathrm{ka}$; in between, and at the beginning of MIS 3 (50-40 ka) the dust accumulation rate was $\sim 50 \%$ lower. Finally, the HB section also records a MIS 2 hiatus of $\sim 17$ ka duration, probably resulting from deflation. 
This study implies that loess deposition on the Tibetan Plateau is predominantly an interglacial/interstadial phenomenon and the TP may be deflating at the same time as the CLP is accumulating, at least during MIS 2.

Chongyi E (echongyi@163.com), School of Geographical Science, Qinghai Normal University, 810008 Xining, P.R. China; Nordic Laboratory for Luminescence Dating, Department of Geoscience, Aarhus University, DTU Risø Campus, DK-4000 Roskilde, Denmark; Center for Nuclear Technologies, Technical University of Denmark, DTU Risø Campus, DK-4000 Roskilde, Denmark; and Qinghai Province Key Laboratory of Physical Geography and Environmental Process, Qinghai Normal University, 810008 Xining, P.R. China; Andrew S. Murray, Nordic Laboratory for Luminescence Dating, Department of Geoscience, Aarhus University, Risø DTU, DK-4000 Roskilde, Denmark; Reza Sohbati and Jan-Pieter Buylaert, Nordic Laboratory for Luminescence Dating, Department of Geoscience, Aarhus University, Risø DTU, DK-4000 Roskilde, Denmark, and Center for Nuclear Technologies, Technical University of Denmark, DTU Risø Campus DK-4000 Roskilde, Denmark; Long Yang, Jie Yuan and Wenting Yan, School of Geographical Science, Qinghai Normal University, 810008 Xining, P.R. China; and Qinghai Province Key Laboratory of Physical Geography and Environmental Process Qinghai Normal University, 810008 Xining, P.R. China; XiangJun Liu, Qinghai Institute of Salt Lakes, Chinese Academy of Sciences, 810008 Xining, P.R. China; received 13th August 2017, accepted 12th April 2018.

The Tibetan Plateau (TP) is the most extensive and most elevated mountain plateau on Earth. Because of its sensitivity to global climatic change it has been referred to as the Third Pole (Qiu 2008). The extensive aeolian deposits on the TP are important environmental archives of past environmental changes, especially the interplay between the Asian monsoon and the Westerly system (Fig. 1A) and the link between dust accumulation and Quaternary glaciations. As a result, understanding the timing of loess 
deposition is crucial to reconstructing both the development of the Quaternary landscape in Tibet and the changes in the broader Asian Quaternary climate (Lehmkuhl et al. 2000; Lu et al. 2004; Li \& Li 2006; Owen et al. 2006; Sun et al. 2007; Lai et al. 2009; Stauch et al. 2012; Lehmkuhl et al. 2014).

There are significant differences between the basal age of loess in interior TP and adjacent areas. For example, the Xining loess on the northeast TP (NETP), a stretch of the Chinese loess plateau, has a basal age of $\sim 2.0 \mathrm{Ma}$ at an elevation of $2300 \mathrm{~m}$ a.s.l. (Lu et al. 2007), whereas the loess on the east TP, including the Ganze loess with an elevation of $3480 \mathrm{~m}$ a.s.I. and the loess-like Chendu clay, have a basal age of 0.8 Ma (Fang et al. 1996; Yang et al. 2010). Most of the existing loess in the interior of Tibet, with a thickness of 1-3 $\mathrm{m}$ and lying above $3000 \mathrm{~m}$ a.s.l., has accumulated since the last deglaciation i.e. 13-14 ka (Sun et al. 2007; Kaiser et al. 2010; Lu et al. 2011; Liu et al. 2012; Stauch et al. 2012; Qiang et al. 2013; Yu \& Lai 2014; Zhang et al. 2015a). Sporadic and discontinuous LGP (Last Glacial Period) loess strata are distributed in Gonghe Basin and Qilian Mountain (Zhang et al. 2015a; Qiang et al. 2016), and some $>70$ ka loess is sandwiched between alluvial gravels (Sun et al. 2007; Liu et al. 2012). The lack of loess associated with full glacial conditions is believed to be a result of either sparse vegetation cover, or the erosion of loess during the beginning of each interglacial (Sun et al. 2007). In addition, loess sedimentation is thought to be discontinuous before $\sim 13 \mathrm{ka}$ (Zhang et al. 2015a), which limits its contribution to understanding the climate change on TP during glacial periods. It is thus important to test these hypotheses by investigating more loess sections on the TP, especially in the inner TP.

In October of 2014, a detailed field investigation was carried out in the source region of Yellow River. There, mantles of sandy loess form a distinct belt with a thickness of 1-20 m covering an elevation ranging between 3500 and $4500 \mathrm{~m}$ a.s.I. on the east-facing slopes of the Anyemaqen Mountains and the terrace of Yellow River. The homogeneous aeolian loess in Hebei county reaches a thickness of $8 \mathrm{~m}$ without any visible intercalated palaeosols, and so the Hebei section offers the opportunity of obtaining high resolution 
palaeoenvironmental information. However, there is little chronological information available for the loess deposits in this region. The purpose of this study is to provide a high-resolution chronology for loess formation in the region using luminescence dating.

\section{Hebei section and sampling}

The Hebei loess section (3443'13"' N, 10048'29" E, 3669 m a.s.I.) is situated on the east-facing slopes of the Anyemaqen Mountains and the north bedrock terrace of Yellow River (Fig. 1B). The Anyemaqen Mountains are formed within a zone of transpression at the easternmost end of the Kunlun fault system, rising from the surrounding peneplain at $4000 \mathrm{~m}$ a.s.l., and reaching a maximum altitude of $6282 \mathrm{~m}$ a.s.I. (Roberts 2012). Moraines, erratics, cirques, trough valleys and other glacial landforms are widespread in the study area, and three terminal moraines in the eastern Anyemaqen Mountain have been dated to 45.5, 16 and 9 ka (Thrasher et al. 2009). The Hebei loess section is located $\sim 100 \mathrm{~km}$ to the east of the Anyemaqen glaciers; the dominant wind direction in the region is from the west, indicating that Hebei loess is probably 'cold loess'. The present climate in the study area is dominated by the Asian monsoon system. Most of the precipitation falls in summer, and a cold and dry continental air mass prevails in winter. The mean annual temperature, precipitation and evaporation in Tongde weather station $60 \mathrm{~km}$ away from the section are $0.5^{\circ} \mathrm{C}, 440 \mathrm{~mm}$ and over $1350 \mathrm{~mm}$, respectively. The landscape of the study area is mostly vegetated by alpine meadow and subalpine steppe.

The loess at the Hebei section is $\sim 8 \mathrm{~m}$ thick and directly overlies pluvial-fluvial gravels. Except for the darker modern soil layer in the top $\sim 10 \mathrm{~cm}$, the whole section is yellowish, loose and homogenous. The average grain-size is coarse silt, between 34 and $45 \mu \mathrm{m}$. There is no obvious calcic horizon or carbonate concretion in the whole loess stratum. Only a small number of snail fossils were found at depths $>6 \mathrm{~m}$. Twenty-nine luminescence samples were taken from the Hebei section at $20-30 \mathrm{~cm}$ intervals in October 2014. All OSL 
samples were obtained by hammering steel tubes $(25 \mathrm{~cm}$ long cylinders with a diameter of $5 \mathrm{~cm}$ ) into a freshly dug vertical section. The tubes were then covered and sealed with cotton, and finally wrapped in plastic and tape to avoid light exposure. At 615 and $720 \mathrm{~cm}$, two groups of well-preserved snails were sampled and sent to Beta Analytics Inc. for accelerator mass spectrometry (AMS) radiocarbon $\left({ }^{14} \mathrm{C}\right)$ dating.

\section{Sample preparation and measurement}

All the samples were prepared and measured in the Nordic Laboratory for Luminescence Dating. Under subdued orange light, the outer 2-3 cm ends of tube samples were removed and reserved for environmental dose rate measurement. The inner part of the sample was wet sieved to the grain-size range 63-90 $\mu \mathrm{m}$. This fraction was treated with $\mathrm{HCl}(10 \%)$ and $\mathrm{H}_{2} \mathrm{O}_{2}(10 \%)$ for $20 \mathrm{~min}$. to remove any carbonates and organic material, and 10\% HF for 40 min. to clean the grains. The treated material was floated in an aqueous heavy liquid solution ('Fastfloat', $\rho=2.58 \mathrm{~g} \mathrm{~cm}^{-3}$ ) to separate quartz-rich and K-rich feldspar fractions. Finally, the quartz-rich fraction was further treated with concentrated HF (i.e. 40\%) for 60 min. to remove any remaining feldspar contamination and the outer alpha-irradiated layer. Any fluoride contamination was removed using $10 \% \mathrm{HCl}$ for $20 \mathrm{~min}$. After each step the samples were washed with deionised water.

Quartz and K-rich feldspar grains were mounted as large aliquots $(8 \mathrm{~mm})$ in a monolayer on 9-mm-diameter stainless steel discs (quartz) and cups (feldspar) using silicone oil. All measurements were carried out on standard Risø TL/OSL DA-20 readers (Bøtter-Jensen et al. 2010). OSL signals from quartz were stimulated by blue LEDs emitting at $470 \mathrm{~nm}$ with a power density of $\sim 80 \mathrm{~mW} \mathrm{~cm}^{-2}$ at sample position and measured through a 7.5-mm Hoya U-340 glass filter. IRSL signals from K-feldspar were stimulated using IR LEDs with peak emission at $870 \mathrm{~nm}$ and a power density of $\sim 135 \mathrm{~mW} \mathrm{~cm}^{-2}$ at sample position and detected through a BG3/BG39 blue filter combination. Beta 
irradiations used a ${ }^{90} \mathrm{Sr} /{ }^{90} \mathrm{Y}$ source mounted on the reader and calibrated for both discs and cups using 180-250 $\mu \mathrm{m}$ calibration quartz grains (Hansen et al. 2015). The heating rate was $5^{\circ} \mathrm{C} \mathrm{s}^{-1}$ throughout.

\section{Environmental dose rate measurement}

The outer 2-3 cm ends of tube samples were used to evaluate the environmental dose rate. Most samples (24) were measured by high resolution gamma spectrometry (Murray et al. 1987). The dose rates for the remaining 5 samples with small amounts of material $(<30 \mathrm{~g})$ were estimated using inductively coupled plasma mass spectrometry (ICP-MS). The material for high resolution gamma spectrometry was homogenized by grinding $(<200 \mu \mathrm{m})$, ignited at $450{ }^{\circ} \mathrm{C}$ for 24 hours to remove organic matter and cast in wax to prevent ${ }^{222} \mathrm{Rn}$ loss and to provide a reproducible counting geometry. The solid disc-shaped sample (>30 g of dry sample) was then stored for at least 3 weeks before measurement to allow ${ }^{222} \mathrm{Rn}$ to build up to equilibrium with its parent ${ }^{226} \mathrm{Ra}$. The resulting radionuclide concentrations (Table 1) were converted into infinite matrix dry dose rates using the conversion factors of Guérin et al. (2012). The cosmic ray contribution was calculated following Prescott \& Hutton (1994), and a water content of $10 \pm 5 \%$ was assumed to apply throughout the burial period. For quartz, an internal dose rate of $0.01 \pm 0.002 \mathrm{~Gy} \mathrm{ka}^{-1}$ was assumed after Vandenberghe et al. (2008). For K-feldspar, an internal beta dose rate was calculated based on an assumed ${ }^{40} \mathrm{~K}$ content of $12.5 \pm 0.5 \%$ (Huntley \& Baril 1997; Zhao \& Li 2005) and an assumed ${ }^{87} \mathrm{Rb}$ content of $400 \pm 100$ p.p.m. (Huntley \& Hancock 2001). A small internal alpha contribution of $0.10 \pm 0.05 \mathrm{~Gy} \mathrm{ka}^{-1}$ was also included from internal ${ }^{238} \mathrm{U}$ and ${ }^{232} \mathrm{Th}$ based on the measurements by Mejdahl (1987). The resulting total dose rates do not vary significantly with depth (Table 1 ).

\section{Luminescence characteristics}

Quartz 
The purity of quartz fractions was examined using the OSL-IR depletion ratio test (Duller 2003). Three aliquots were measured from each sample. The average OSL-IR depletion ratio was $0.96 \pm 0.005(n=87)$, implying that any feldspar contamination of the OSL signal from these samples is negligible. A standard quartz OSL single-aliquot regenerative (SAR) dose protocol was used for $D_{e}$ measurements (Murray \& Wintle 2000; Wintle \& Murray 2006). Fig. $2 \mathrm{~A}$ shows the dose-response and (inset) stimulation curves for one of the samples. The OSL signal was rapidly bleached to background level within two seconds (Fig. 2A) and is dominated by the fast component. The net quartz OSL signal used for calculations was derived from the initial $0.32 \mathrm{~s}$ of the signal (first two channels) minus an early background from the following two channels i.e. 0.32 to 0.64 s (Ballarini et al. 2007; Cunningham \& Wallinga 2010).

In order to select the appropriate preheat conditions for $D_{e}$ determination, natural (Fig. 2B) and dose-recovery preheat-plateau (Fig. 2C) tests were conducted for three samples from the top (153001, depth $10 \mathrm{~cm})$, middle (153013, depth $400 \mathrm{~cm}$ ) and bottom $(153029$, depth $760 \mathrm{~cm})$ of the section. The preheat temperature prior to the measurement of natural and regenerated signals varied from 160 to $300{ }^{\circ} \mathrm{C}$ with $20{ }^{\circ} \mathrm{C}$ increments, and the cut-heat temperature preceding the measurement of the test-dose signal was generally $40{ }^{\circ} \mathrm{C}$ (i.e. $160-260^{\circ} \mathrm{C}$ ) below the preheat temperature except for preheat temperatures of 160 and $180^{\circ} \mathrm{C}$, for which the cut-heat temperature was kept at $160^{\circ} \mathrm{C}$. For sample 153001 there is a $D_{e}$ plateau from 180 to $280{ }^{\circ} \mathrm{C}$ (Fig. 2B). $A D_{e}$ plateau also appears from 180 to $240{ }^{\circ} \mathrm{C}$ for samples 153013 and153029, while at $>240{ }^{\circ} \mathrm{C}, \mathrm{D}_{e}$ values increase steadily with elevated temperature (Fig. 2B).

In dose-recovery preheat-plateau tests, fresh aliquots from the same samples were bleached twice with blue light for $100 \mathrm{~s}$ at room temperature, separated by a pause of $10 \mathrm{ks}$. Then, a known laboratory beta dose close to the expected $D_{e}$ (based on an estimate determined as part of the purity test) was given to these aliquots and measured in a similar manner to the natural dose. For all three samples, the dose recovery ratios are in agreement with 
unity within the error limits over the preheat temperature range of $200-260{ }^{\circ} \mathrm{C}$ (Fig.2C). Based on these results a preheat temperature of $200{ }^{\circ} \mathrm{C}$ (for $10 \mathrm{~s}$ ) and a cut-heat temperature of $160{ }^{\circ} \mathrm{C}$ was identified as suitable for the measurement of these samples (Table 2).

In order to verify the general suitability of the preheat and cut-heat temperatures selected above, further dose-recovery tests were carried out on all 29 samples (3-6 aliquots each). Fig. 3 presents a histogram of the measured to given dose ratios. The average ratio was $1.009 \pm 0.015(n=135)$ for all the samples. However for some older samples especially these of which the dose is larger than $120 \mathrm{~Gy}$, the given dose cannot be recovered accurately.

\section{K-feldspar}

The greatest factor hampering the use of feldspars in luminescence dating is the effect of anomalous fading of the luminescence signal (Wintle 1973). Since the reporting of lower fading rates from post-IR IRSL (pIRIR) signals measured at elevated temperature, compared to those from the conventional IRSL measured at $50{ }^{\circ} \mathrm{C}$ (Thomsen et al. 2008), different pIRIR procedures have been developed to minimize the effects of fading, including a two-step (Buylaert et al. 2009; Thiel et al. 2011; Buylaert et al. 2012) and a multiple elevated temperature (MET) post-IR IR stimulation procedure (Li \& Li 2011, 2012). The robustness of ages based on pIRIR protocols without fading correction has been confirmed by comparison with independent ages from different sedimentary samples around the world (Buylaert et al. 2012; Arnold et al. 2015). In our study, a series of measurements, including fading rate, preheat plateau, dose recovery and bleachability tests under a wide range of preheat and stimulation temperatures were carried out to investigate the luminescence characteristics of pIRIR and IR ${ }_{50}$ signals from sand-sized (63-90 $\mu \mathrm{m}) \mathrm{K}$-feldspar extracts. For these different tests, twenty-four aliquots were prepared from samples 153001 and 153013. A preheat, varying from 180 to $320{ }^{\circ} \mathrm{C}$ with $20^{\circ} \mathrm{C}$ increments, was given prior to the measurements of the natural and regenerative dose as well as the test dose. The first IR stimulation 
was carried out at $50{ }^{\circ} \mathrm{C}$ for $200 \mathrm{~s}\left(\mathrm{IR}_{50}\right)$, followed by the second stimulation for $200 \mathrm{~s}$ with an elevated temperature (pIRIR) $30^{\circ} \mathrm{C}$ below the preheat temperature. At the end of the pIRIR response to each test dose, a $200 \mathrm{~s}$ 'hot' IR bleach at a temperature $5^{\circ} \mathrm{C}$ higher than preheat temperature was used to ensure a low residual of IRSL signal for the next cycle. The net IRSL signal from K-feldspar was integrated from the first $1 \mathrm{~s}$ of stimulation minus the last $10 \mathrm{~s}$ as background. The detailed protocol is shown in Table 2 .

Fig. 4 shows the $I R_{50}$ and pIRIR ${ }_{170}$ stimulation and dose response curves for sample 153013 . The $I_{50}$ signal intensity is higher than the pIRIR ${ }_{170}$ signal.

Fig. 5 summarizes the equivalent dose, residual dose (after $4 \mathrm{~h}$ bleaching in solar simulator) and dose recovery ratio of $\mathrm{IR}_{50}$ and pIRIR signals as a function of preheat temperature for samples 153001 and 153013 . Fig. 5A shows the mean $D_{e}$ values obtained for the first $I R_{50}$ stimulation with various preheat temperatures. There is no systematic trend in $D_{e}$ with the preheat temperature used prior to the $\mathrm{IR}_{50}$ measurement, which is consistent with the observations of Murray et al. (2009). This observation in HB loess also concurs with Alaskan loess (Roberts 2012), and Qilian Shan loess (northeastern margin of TP) (Zhang et al. 2015a). In contrast to the $\mathrm{IR}_{50}$ data, the pIRIR data indicate a plateau up to $220^{\circ} \mathrm{C}$, beyond which there is a systematic increase in dose with increasing preheat temperatures (from 280 to $320^{\circ} \mathrm{C}$ ) and stimulation temperatures (from 250 to $290^{\circ} \mathrm{C}$ ) (Fig. 5B).

It is known that elevated-temperature IRSL bleaches more slowly than IRSL stimulated at low temperatures (Poolton et al. 2002), and there may be a residual component left even after a prolonged bleaching period (e.g. Kars et al. 2014; Sohbati et al. 2016; Yi et al. 2016). The residual IR ${ }_{50}$ and pIRIR doses plotted as a function of preheat temperature are shown in Fig. $5 \mathrm{C}$ and $\mathrm{D}$, respectively. For both $\mathrm{IR}_{50}$ and pIRIR signals, the residual doses gradually increase with the preheat and stimulation temperatures, and larger residual doses were obtained from the sample having larger $D_{e}$ value (i.e. 153013), in agreement with previous observations (e.g. Buylaert et al. 2012; Sohbati et al. 2012; Zhang et al. 2015b). 
The $I_{50}$ and pIRIR fading rates (g-values) of sample 153013 were measured at different preheat temperatures, following Auclair et al. (2003) and calculated after Huntley \& Lamothe (2001) (Fig. 5 E, F). The IR 50 g-value shows an apparent decreasing trend with increasing preheat temperature varying from $2.9 \pm 0.3 \%$ /decade to $1.43 \pm 0.15 \%$ /decade, which is surprising in view of the absence of any significant dependence of $D_{e}$ on preheat temperature. All pIRIR signals fade much less than the $I{ }_{50}$ signals; the measured fading rates ranging between $0.84 \pm 0.16 \% /$ decade and $0.23 \pm 0.07 \% /$ decade and tend to decrease slightly with increasing preheat and stimulation temperatures. The lower fading rate and thus higher signal stability with increasing preheat/stimulation temperature is in line with the previous observations (e.g. Jain \& Ankjærgaard, 2011). All measured pIRIR fading rates are less than $1 \% /$ decade; others have suggested that such low fading rates may be laboratory artefacts (Thiel et al. 2011; Buylaert et al. 2012; Roberts 2012). In light of this, we have chosen not to fading correct for the observed g-value.

For dose recovery tests, a laboratory beta dose equivalent to the average $D_{e}$ value of the natural preheat plateaus (i.e. $\sim 40$ Gy for 153001 , and $\sim 170$ Gy for 153013) was added to aliquots which had been reset by 4 hours of light exposure in a Hönle SOL2 solar simulator. Residual and added doses were then measured as an 'unknown' dose using the same pIRIR protocol. The recovered dose (Fig. 5G, H) was derived by subtracting the residual dose following a $4 \mathrm{~h}$ bleach (Fig. 5C, D) from the doses measured following bleaching and dosing. For the $\mathrm{IR}_{50}$ signals, the dose recovery ratio is satisfactory over the preheat temperature range from 180 to $220^{\circ} \mathrm{C}$. For the pIRIR signals, all of the dose recovery ratios except for 240 and $260{ }^{\circ} \mathrm{C}$ of sample 153013 are within $10 \%$ of unity (Fig. $5 \mathrm{H}$ ). Given the low residual dose of pIRIR 170 , the lower fading rate, and the excellent dose recovery ratio for both $\mathrm{IR}_{50}$ and pIRIR 170 at preheat temperature of $200{ }^{\circ} \mathrm{C}$, a SAR protocol using pIRIR $_{170}$ was empolyed to date the HB loess section. The pIRIR 170 signal used in this study is generally similar in behaviour to that from a loess section in Arid Central Asia described by Li et al. (2015); they also describe a low residual 
dose (<1.3 Gy) and low fading rate ( 1\%/dec.). Here, we measured $12-15$ cups for each sample to give the mean $D_{e}$ (and associated standard error).

\section{Bleaching characteristics}

The completeness of the bleaching of quartz can be determined based on the differential bleaching rates of quartz and feldspar luminescence signals (Murray et al. 2012). The quartz OSL signal decreases much more rapidly than the $\mathrm{IR}_{50}$ and pIRIR signals during broadband stimulation; after $\sim 30 \mathrm{~s}$ bleaching the quartz OSL in sample 153003 has been reduced to $\sim 5 \%$ of its original level, while the feldspar $I_{50}$ and pIRIR 170 signals are still at $\sim 24$ and $\sim 65 \%$, respectively (Fig. $6 \mathrm{~A}$ ). It takes $\sim 240 \mathrm{~s}$ to reduce the $\mathrm{IR}_{50}$ signal to a negligible level $(\sim 3.8 \%)$, while it takes $7200 \mathrm{~s}$ to reduce pIRIR ${ }_{170}$ signal to a similar level $(\sim 5 \%$, Fig. $6 \mathrm{~A})$. Fig. $6 \mathrm{C}$ shows the very strong correlation between $\mathrm{D}_{e}$ values based on $I_{50}$ and pIRIR 170 over the entire dose range. Either all samples have been incompletely-bleached to the same degree or, more likely, all samples have been completely bleached (see also Sohbati et al. 2016).

The dependence of both $I R_{50}$ and pIRIR 170 residual doses on solar bleaching time was also investigated. Nine sets of aliquots from sample 153003 were bleached under the solar simulator for various times from $1 \mathrm{~h}$ to $256 \mathrm{~h}$; the residual doses were then measured using the same pIRIR ${ }_{170}$ protocol. The bleaching rate of $\mathrm{IR}_{50}$ and pIRIR ${ }_{170}$ decreases with stimulation time (Fig. 6B). For the $\mathrm{IR}_{50}$ signal, the residual dose is reduced to $1.04 \pm 0.03 \mathrm{~Gy}, \sim 1.3 \%$ of the natural dose of $76 \mathrm{~Gy}$, after only $1 \mathrm{~h}$ of SOL2 exposure; it then continues to decrease slowly. For the pIRIR ${ }_{170}$ signal, the residual dose is reduced relatively quickly over the first $4 \mathrm{~h}$ of bleaching, decreasing from a natural dose of 97 to 4.3 Gy i.e. $<5 \%$ of the natural dose. After $4 \mathrm{~h}$ bleaching, the dose recorded by the pIRIR 170 signal continues to decrease slowly. Both the $\mathrm{IR}_{50}$ and pIRIR 170 signals are still decreasing after 11 days of solar stimulator exposure (see also Kars et al. 2014). Given these observations, and the absence of any significant intercept in Fig. 6C, no residual dose was subtracted in any of our age calculations; this is a conservative calculation 
since the main use of the feldspar ages is to confirm the degree of bleaching of the quartz at deposition.

\section{HB loess age}

Quartz OSL and K-feldspar IR $\mathrm{R}_{50}$ and pIRIR 170 equivalent doses and ages are summarized in Table 3. Fig. 7A summarizes the comparison between OSL and fading-corrected $I \mathrm{I}_{50}$ ages. For the $\mathrm{IR}_{50}$ ages, the g-value of $\sim 2.6 \% / \mathrm{dec}$. measured from the sample 153013 was applied to all samples, and the correction follows Huntley \& Lamothe (2001). Note that following the observations of Buylaert et al. (2011) and Singh et al. (2017), we do not attempt to apply aliquot- or sample-specific fading rates. As expected, uncorrected $\mathrm{IR}_{50}$ ages underestimate those from quartz. After application of the fading correction, the $I_{50}$ ages tend to overestimate those from quartz especially at higher doses (equivalent to $>40 \mathrm{ka}$ ). On the other hand, pIRIR 170 and quartz ages show good agreement for samples whose quartz age is $<40$ ka (Fig. 7B); for samples with quartz ages $>40$ ka (i.e. $D_{e}>120 \mathrm{~Gy}$ ) the pIRIR $_{170}$ ages tend to be older than quartz ages. This is not surprising as it has often been reported that quartz tends to underestimate age for doses greater than 150 Gy (e.g. Chapot et al. 2012; Timar-Gabor \& Wintle 2013). As a result, we restrict our use of quartz ages to $D_{e}<120 \mathrm{~Gy}$; this observation is consistent with previous work on the western Chinese loess plateau (e.g. Buylaert et al. 2007; Buylaert et al. 2008) and Tianshan Mountains, arid central Asia (e.g. Li et al. 2016).

The corrected $I R_{50}$ and pIRIR 170 ages from these samples are similar to one another; since the $I_{50}$ signal bleaches more rapidly than pIRIR signals (e.g. Colarossi et al. 2015), this probably indicates that both feldspar signals are fully bleached. However, the quartz ages from the upper two samples with depth of 10 and $40 \mathrm{~cm}$ are significantly younger than the feldspar ages. This suggests a very short, recent bleaching event, sufficient to reset quartz OSL, at least partially, but not sufficient to significantly affect feldspar signals. This 
would be consistent with agricultural disturbance, and in turn suggests that these two quartz ages cannot be used as reliable indicators of primary deposition time. On the other hand, the feldspar ages from these samples probably do give a more accurate indication of primary deposition, and suggest a minimum age of the loess deposit of $10.8 \pm 0.5 \mathrm{ka}$.

Finally, two radiocarbon ages obtained from the well-preserved snails at depths of 615 and $725 \mathrm{~cm}$ are $40.1 \pm 0.6 \mathrm{ka} \mathrm{BP}(42.8-44.8 \mathrm{cal}$. ka BP) and 39.8 \pm 0.4 ka BP (42.8-44.2 cal. ka BP), respectively. Both these ages are approaching the practical age limit for ${ }^{14} \mathrm{C}$. Because of the dose rate, this age range happens to be in the same dose range at which quartz begins to systematically underestimate (see above). Thus the apparent agreement between ${ }^{14} \mathrm{C}$ and quartz ages in the deeper samples is probably coincidental; both are likely underestimates. At this stage in our work, we assume that the older feldspar ages at this depth and below is more likely to be correct. This conclusion is consistent with those of previous studies in Xinjiang mountain loess, western China (E et al. 2012; Song et al. 2015).

Given that the consistency between quartz and feldspar age for samples younger than $40 \mathrm{ka}$, and the known underestimate of quartz in loess $>40 \mathrm{ka}$, the average quartz OSL and pIRIR 170 feldspar ages were taken to represent the aeolian loess deposition ages up to $40 \mathrm{ka}$ and the feldspar ages alone used beyond that. The ages of sample 153005 and 153006 are obviously outliers, and these two ages have been excluded from further analysis. The final accepted ages are plotted as a function of depth in Fig. 8A together with the ${ }^{14} \mathrm{C}$ ages. An age-depth model derived using the Bacon code (Blaauw \& Christen 2011) is also shown (solid blue line) fitted to the accepted luminescence ages from $40 \mathrm{~cm}$ and below; 65\% confidence intervals are shown as solid green lines. Finally, mass accumulation rates (MAR) are derived from the modelled fit (Fig. 8B), assuming a loess density of $1.50 \mathrm{~g} \mathrm{~cm}^{-3}$ (Kohfeld \& Harrison 2003; Buylaert et al. 2015).

\section{Discussion}


The HB loess section appears to record continuous environmental information from $\sim 50$ to $\sim 30 \mathrm{ka}$, i.e. throughout the relatively warm and humid Marine Isotope Stage (MIS) 3 (Voelker 2002). There was considerable variation in MAR during MIS 3 at the HB section. Dust accumulation was relatively constant at $\sim 350 \mathrm{~g} \mathrm{~m}^{-2} \mathrm{a}^{-1}$ between $\sim 50$ and $\sim 40 \mathrm{ka}$, but then rapidly doubled at $\sim 38 \mathrm{ka}$. MAR then decreased to the earlier level, with a minimum rate at $\sim 33$ ka before increasing again after $\sim 32$ ka (Fig. 8B). We first compare our record with Huangshuiping loess section at the margin of northeast TP (located in Fig.1B) and then with a central CLP site. The similar rapid dust deposition event around 30-33 ka was recorded in the Hongshuiping loess section (Wang et al. 2015). The flux of $>25 \mu \mathrm{m}$ fraction grains (considered as an indicator of the aeolian contribution) to the lake sediments in Qinghai lake also suggests a rapid accumulation rate between 32 and 29 ka (An et al. 2012). Both studies are in line with our high MAR value at $\sim 32 \mathrm{ka}$. The relatively low and stable dust accumulation rate between $\sim 50$ and $\sim 40$ ka at our site (Fig. 8B) may indicate a relatively weak dust source during early MIS 3, perhaps because of increased vegetation cover, a mechanism suggested by Ujvari et al. (2017) for European loess. Comparison between our MAR data and those of Stevens et al. (2016) from the central CLP (Xifeng site; Fig. S1) shows a similar MAR pattern for MIS 3. However, the Xifeng data indicate much lower MAR values ( $25 \%$ of $\mathrm{HB}$ ) although the relative change from low to high MAR values is similar (approximately double).

In contrast to the continuous MIS 3 record, almost all of MIS 1 and the entire MIS 2 are missing at Hebei (Fig. 8) - even the presence of sediment from MIS 1 at this site is demonstrated only by a sample that was probably exposed to light after primary deposition. The lack of MIS 1 dates is in contrast to previous work, which suggests that in most regions of the TP the most rapid loess accumulation occurred during the Lateglacial and in the early Holocene (based on 353 OSL ages from in total 109 individual sections, Stauch 2015). Furthermore, in our study area, the basal age of the Holocene SHD loess section, $\sim 80 \mathrm{~km}$ south of our HB section, is $10.7 \pm 1 \mathrm{ka}$ (Lehmkuhl et al. 2014), and two OSL dates on two till sections of loess composition near the 
Anyemaqen Mountains are 12.3 \pm 1.1 and 7.1 $\pm 0.7 \mathrm{ka}$ (Owen et al. 2003). Combined with the top sample age of $10.8 \pm 0.5 \mathrm{ka}$ in the HB section, these published dates indicate that deposition of loess continued during the Holocene and the Lateglacial (Owen et al. 2003; Lehmkuhl et al. 2014).

However, there are almost no published loess dates from the TP that fall during the Last Glacial Maximum (LGM, from $\sim 26$ to $\sim 19$ ka ago). For instance, Buylaert et al. (2008) identified an important hiatus between $\sim 20$ and $\sim 30 \mathrm{ka}$ at the Tuxiangdao site on the margin of the northeast TP. In addition, low dust accumulation rates $\left(<5 \mathrm{~cm} \mathrm{ka}^{-1}\right.$ for TX loess section and $\sim 10 \mathrm{~cm} \mathrm{ka}^{-1}$ for $\mathrm{ML}$ loess section) can be calculated from the published data for the ML and TX loess sections in the Gonghe basin during the LGM (Qiang et al. 2016), although this is based on a limited number of ages. In our view an erosional hiatus in these sequences is a more likely explanation, similar to that found in our HB section (Fig. 8A); the alternative of prolonged low accumulation rates seems less likely in such a dynamic intramontane basin. Fig. 9 summarizes the distribution of loess-palaeosol luminescence ages in the northeast TP (based on our data and data from Küster et al. 2006; Lu et al. 2011; Liu et al. 2012; Stauch et al. 2012; Liu et al. 2013; Qiang et al. 2013; Lehmkuhl et al. 2014; Yu \&Lai 2014; Liu et al. 2015; Zhang et al. 2015a; Qiang et al. 2016; Liu et al. 2017). It can be seen that loess deposition in Tibet is predominantly an interglacial/interstadial phenomenon. However it must be recognized that, except for the HB section, the other sections were sampled at a relatively low spatial (depth) resolution, and more high resolution chronological studies are required to confirm this hypothesis.

In contrast, dust deposition and high MAR values in the CLP seem to occur mainly during glacial periods (e.g. Kang et al. 2015) suggesting that the TP may be deflating at the same time as the CLP is accumulating, at least during MIS 2. The obvious inference that the TP provides at least part of the source of CLP loess is consistent with the conclusions of recent provenance studies (Bird et al. 2015; Nie et al. 2015; Fenn et al. 2017). 


\section{Conclusions}

A high sampling resolution chronological study was carried out at the HB loess section on east-facing slopes of the Anyemaqen Mountains in the northeast TP. Both quartz OSL and feldspar IRSL signals were used to derive ages. Quartz OSL and feldspar pIRIR 170 ages are in good agreement back to $\sim 40 \mathrm{ka}$ (corresponding quartz $\mathrm{D}_{e} \sim 120 \mathrm{~Gy}$ ). Beyond this, feldspar pIRIR 170 ages are considered more reliable. The agreement between quartz and feldspar ages up to $\sim 40$ ka confirms that both signals are sufficiently well bleached in this age range, and so it is reasonable to conclude that older feldspar samples were also well bleached. We deduce that quartz $D_{e}$ values obtained from the SAR protocol used here with sand-sized $(63-90 \mu \mathrm{m})$ grains should not be considered reliable above $\sim 120 \mathrm{~Gy}$. The HB loess section records continuous environmental information of the entire MIS 3 period (50-30 ka). Calculated mass accumulation rates (MAR) varied considerably over this period. During early MIS 3 (50-40 ka) dust accumulation was relatively low and stable but then rapidly increased to peak at $\sim 38 \mathrm{ka}$. MAR values then decreased to reach a low at $\sim 33 \mathrm{ka}$; after $\sim 32$ ka MAR values almost doubled within a few ka. Our results also suggest an erosional hiatus during MIS 2 which is in line with the absence of MIS 2 loess ages on the TP. We suggest that loess deposition on the Tibetan Plateau is predominantly an interglacial/interstadial phenomenon but more high resolution chronological studies, especially in the central TP, are required to fully test this hypothesis.

Acknowledgements.- This study was supported by a China NSF grant (41761042), NSF grant of Qinghai Province (2017-ZJ-901), and CAS "Light of West China" Program (2018-3-10). Alastair Cunningham is thanked for help with the Kernel density plot. Thomas Stevens is thanked for useful discussions. We thank the anonymous reviewers for providing valuable comments on the manuscript and Li Fan for his help in the field. 


\section{References}

An, Z., Colman, S. M., Zhou, W., Li, X., Brown, E. T., Jull, A. T., Cai, Y., Huang, Y., Lu, X. \& Chang, H. 2012: Interplay between the Westerlies and Asian monsoon recorded in Lake Qinghai sediments since $32 \mathrm{ka}$. Scientific Reports 2, 1-7.

An, Z., Kukla, G., Porter, S. C. \& Xiao, J. 1991: Late quaternary dust flow on the chinese Loess Plateau. Catena 18, 125-132.

Arnold, L.J., Demuro, M., Parés, J.M., Pérez-González, A., Arsuaga, J.L., Bermúdez de Castro, J.M. \& Carbonell, E., 2015: Evaluating the suitability of extended-range luminescence dating techniques over early and Middle Pleistocene timescales: Published datasets and case studies from Atapuerca, Spain. Quaternary International 389, 167-190.

Ballarini, M., Wallinga, J., Wintle, A. G. \& Bos, A. J. J. 2007: A modified SAR protocol for optical dating of individual grains from young quartz samples. Radiation Measurements 42, 360-369.

Blaauw, M. \& Christen, J. A. 2011: Flexible paleoclimate age-depth models using an autoregressive gamma process. Bayesian Analysis 6, 457-474.

Bøtter-Jensen, L., Thomsen, K. J. \& Jain, M. 2010: Review of optically stimulated luminescence (OSL) instrumental developments for retrospective dosimetry. Radiation Measurements 45, 253-257.

Bird, A., Stevens, T., Rittner, M., Vermeesch, P., Carter, A., Andò, S., Garzanti, E., Lu, H., Nie, J., Zeng, L., Zhang, H. \& Xu, Z. 2015: Quaternary dust source variation across the Chinese Loess Plateau. Palaeogeography, Palaeoclimatology, Palaeoecology 435, 254-264.

Buylaert, J.-P., Yeo, E.-Y., Thiel, C., Yi, S., Stevens, T., Thompson, W., Frechen, M., Murray, A., Lu, H., 2015: A detailed post-IR IRSL chronology for the last interglacial soil at the Jingbian loess site (northern China). Quaternary Geochronology 30, 194-199.

Buylaert, J.-P., Jain, M., Murray, A. S., Thomsen, K. J., Thiel, C. \& Sohbati, R. 2012: A robust feldspar luminescence dating method for Middle and Late Pleistocene sediments. Boreas 41, 435-451.

Buylaert, J.-P., Murray, A., Vandenberghe, D., Vriend, M. \& De Corte, F. 2008: Optical dating of Chinese loess using sand-sized quartz: Establishing a time frame for Late Pleistocene climate changes in the western part of the Chinese Loess Plateau. Quaternary Geochronology 3, 99-113.

Buylaert, J. P., Murray, A. S., Thomsen, K. J. \& Jain, M. 2009: Testing the potential of an elevated temperature IRSL signal from K-feldspar. Radiation Measurements 44, 560-565.

Buylaert, J. P., Vandenberghe, D., Murray, A. S., Huot, S., De Corte, F. \& Van den Haute, P. 2007: Luminescence dating of old (>70 ka) Chinese loess: A comparison of single-aliquot OSL and IRSL techniques. Quaternary Geochronology 2, 9-14.

Chapot, M. S., Roberts, H. M., Duller, G. A. T. \& Lai, Z. P. 2012: A comparison of natural- and laboratory-generated dose response curves for quartz optically stimulated luminescence signals from Chinese Loess. Radiation Measurements 47, 1045-105.

Cunningham, A. C. \& Wallinga, J. 2010: Selection of integration time intervals for quartz OSL decay curves. Quaternary Geochronology 5, 657-666.

Daut, G., Mäusbacher, R., Baade, J., Gleixner, G., Kroemer, E., Mügler, I., Wallner, J., Wang, J. \& Zhu, L. 2010: Late Quaternary hydrological changes inferred from 
lake level fluctuations of Nam Co (Tibetan Plateau, China). Quaternary International 218, 86-93.

Duller, G. A. T. 2003: Distinguishing quartz and feldspar in single grain luminescence measurements. Radiation Measurements 37, 161-165.

E, C., Lai, Z., Sun, Y., Hou, G., Yu, L. \& Wu, C. 2012: A luminescence dating study of loess deposits from the Yili River basin in western China. Quaternary Geochronology 10, 50-55.

Fang, X., Chen, F., Shi, Y. \& Li, J. 1996: Garze loess and the evolution of the cryosphere on the Tibetan Plateau. Journal of Glaciology and Geocryology 18, 193-200 (in Chinese).

Fenn, K., Stevens, T., Bird, A., Limonta, M., Rittner, M., Vermeesch, P., Andò, S., Garzanti, E., Lu, H., Zhang, H. \&. Lin, Z. 2017: Insights into the provenance of the Chinese Loess Plateau from joint zircon $\mathrm{U}-\mathrm{Pb}$ and garnet geochemical analysis of last glacial loess. Quaternary Research, Doi:10.1017/qua.2017.86

Guérin, G., Mercier, N., Nathan, R., Adamiec, G. \& Lefrais, Y. 2012: On the use of the infinite matrix assumption and associated concepts: A critical review. Radiation Measurements 47, 778-785.

Hansen, V., Murray, A., Buylaert, J.-P., Yeo, E.-Y. \& Thomsen, K. 2015: A new irradiated quartz for beta source calibration. Radiation Measurements 81 , 123-127.

Huntley, D. J. \& Baril, M. R. 1997: The K content of the K-feldspars being measured in optical dating or in thermoluminescence dating. Ancient TL 15, 11-13.

Huntley, D. J. \& Lamothe, M. 2001: Ubiquity of anomalous fading in K-feldspars and the measurement and correction for it in optical dating. Canadian Journal of Earth Sciences 38, 1093-1106.

Huntley, D.J. \& Hancock, R.G.V. 2001: The Rb contents of the K-feldspar grains being measured in optical dating. Ancient TL 19, 43-46.

Jain, M. \& Ankjærgaard, C., 2011: Towards a non-fading signal in feldspar: Insight into charge transport and tunnelling from time-resolved optically stimulated luminescence. Radiation Measurement 46, 292-309.

Kaiser, K., Lai, Z., Schneider, B. \& Junge, F. W. 2010: Late Pleistocene genesis of the middle Yarlung Zhangbo Valley, southern Tibet (China), as deduced by sedimentological and luminescence data. Quaternary Geochronology 5, 200-204.

Kang, S. G., Roberts, H. M., Wang, X. L., An, Z. S. \& Wang, M. 2015: Mass accumulation rate changes in Chinese loess during MIS 2, and asynchrony with records from Greenland ice cores and North Pacific Ocean sediments during the Last Glacial Maximum. Aeolian Research 19, 251-258.

Kars, R. H., Reimann, T., Ankjærgaard, C. \& Wallinga, J. 2014: Bleaching of the post-IR IRSL signal: new insights for feldspar luminescence dating. Boreas 43, 780-791.

Kohfeld K.E. \& Harrison, S.P. 2003: Glacial-interglacial changes in dust deposition on the Chinese Loess Plateau. Quaternary Science Reviews 22, 1859-1878.

Küster, Y., Hetzel, R., Krbetschek, M. \&Tao, M.X. 2006: Holocene loess sedimentation along the Qilian Shan (China): significance for understanding the processes and timing of loess deposition. Quaternary Science Reviews 25, 114-125.

Lai, Z., Kaiser, K. \& Brückner, H. 2009: Luminescence-dated aeolian deposits of late Quaternary age in the southern Tibetan Plateau and their implications for landscape history. Quaternary Research 72, 421-430. 
Lehmkuhl, F., Klinge, M., Rees-Jones, J. \& Rhodes, E. J. 2000: Late Quaternary aeolian sedimentation in central and south-eastern Tibet. Quaternary International 68-71, 117-132.

Lehmkuhl, F., Schulte, P., Zhao, H., Hülle, D., Protze, J. \& Stauch, G. 2014: Timing and spatial distribution of loess and loess-like sediments in the mountain areas of the northeastern Tibetan Plateau. Catena 117, 23-33.

Li, B. \& Li, S.-H. 2006: Comparison of estimates using the fast component and the medium component of quartz OSL. Radiation Measurements 41, 125-136.

Li, B. \& Li, S.-H. 2011: Luminescence dating of K-feldspar from sediments: A protocol without anomalous fading correction. Quaternary Geochronology 6, 468-479.

Li, B. \& Li, S.-H. 2012: Luminescence dating of Chinese loess beyond 130 ka using the non-fading signal from K-feldspar. Quaternary Geochronology 10, 24-31.

Li, G., Wen, L., Xia, D., Duan, Y., Rao, Z., Madsen, D. B., Wei, H., Li, F., Jia, J. \& Chen, F. 2015: Quartz OSL and K-feldspar pIRIR dating of a loess/paleosol sequence from arid central Asia, Tianshan Mountains, NW China. Quaternary Geochronology 28, 40-53.

Li, G., Rao, Z., Duan, Y., Xia, D., Wang, L., Madsen, D. B., Jia, J., Wei, H., Qiang, M., Chen, J. \& Chen, F. 2016: Paleoenvironmental changes recorded in a luminescence dated loess/paleosol sequence from the Tianshan Mountains, arid central Asia, since the Penultimate Glaciation. Earth and Planetary Science Letters $448,1-12$.

Liu, B., Jin, H., Sun, L., Sun, Z., Su, Z., \& Zhang, C 2013: Holocene climatic change revealed by aeolian deposits from the gonghe basin, northeastern qinghai-tibetan plateau. Quaternary International 296, 231-240.

Liu, X.-J., Xiao, G., E, C., Li, X., Lai, Z., Yu, L. \& Wang, Z. 2017: Accumulation and erosion of aeolian sediments in the northeastern Qinghai-Tibetan Plateau and implications for provenance to the Chinese Loess Plateau. Journal of Asian Earth Sciences 135, 166-174.

Liu, X., Lai, Z., Yu, L., Sun, Y. \& Madsen, D. 2012: Luminescence chronology of aeolian deposits from the Qinghai Lake area in the Northeastern Qinghai-Tibetan Plateau and its palaeoenvironmental implications. Quaternary Geochronology $10,7-43$.

Lu, H., Wang, X. \& Sun X. 2007: Loess stratigraphy and palaeoclimate changes during Quaternary in North Eastern Tibetan Plateau revealed by loess core. Quaternary Sciences 27, 230-241.

Lu, H., Wang, X., Ma, H., Tan, H., Vandenberghe, J., Miao, X., Li, Z., Sun, Y., An, Z. \& Cao, G. 2004: The Plateau Monsoon variation during the past $130 \mathrm{kyr}$ revealed by loess deposit at northeast Qinghai-Tibet (China). Global and Planetary Change 41, 207-214.

Lu, H., Zhao, C., Mason, J., Yi, S., Zhao, H., Zhou, Y., Ji, J., Swinehart, J. \& Wang, C. 2011: Holocene climatic changes revealed by aeolian deposits from the Qinghai Lake area (northeastern Qinghai-Tibetan Plateau) and possible forcing mechanisms. The Holocene 21, 297-304.

Mejdahl, V. 1987: Internal radioactivity in quartz and feldspar grains. Ancient TL 5, 10-17.

Mischke, S., Zhang, C., Börner, A. \& Herzschuh, U. 2010: Lateglacial and Holocene variation in aeolian sediment flux over the northeastern Tibetan Plateau recorded by laminated sediments of a saline meromictic lake. Journal of Quaternary Science 25, 162-177.

Murray, A. S., Buylaert, J. P., Thomsen, K. J. \& Jain, M. 2009: The effect of preheating on the IRSL signal from feldspar. Radiation Measurements 44, 554-559. 
Murray, A. S., Marten, R., Johnston, A. \& Martin, P. 1987: Analysis for naturally occuring radionuclides at environmental concentrations by gamma spectrometry. Journal of Radioanalytical and Nuclear Chemistry 115, 263-288.

Murray, A. S., Thomsen, K. J., Masuda, N., Buylaert, J. P. \& Jain, M. 2012: Identifying well-bleached quartz using the different bleaching rates of quartz and feldspar luminescence signals. Radiation Measurements 47, 688-695.

Murray, A. S. \& Wintle, A. G. 2000: Luminescence dating of quartz using an improved single-aliquot regenerative-dose protocol. Radiation Measurements 32, 57-73.

Murray, A. S. \& Wintle, A. G. 2003: The single aliquot regenerative dose protocol: potential for improvements in reliability. Radiation Measurements 37, 377-381.

Nie, J., Stevens, T., Rittner, M., Stockli, D., Garzanti, E., Limonta, M., Bird, A., Andò, S., Vermeesch, P., Saylor, J., Lu, H., Breecker, D., Hu, X., Liu, S., Resentini, A., Vezzoli, G., Peng, W., Carter, A., Ji, S. \& Pan, B. 2015: Loess plateau storage of northeastern Tibetan plateau-derived yellow river sediment. Nature

Communications 6, 8511. DOI: 10.1038/ncomms9511.

Owen, L. A., Finkel, R. C., Haizhou, M. \& Barnard, P. L. 2006: Late Quaternary landscape evolution in the Kunlun Mountains and Qaidam Basin, Northern Tibet: A framework for examining the links between glaciation, lake level changes and alluvial fan formation. Quaternary International 154-155, 73-86.

Owen, L. A., Finkel, R. C., Haizhou, M., Spencer, J. Q., Derbyshire, E., Barnard, P. L. \& Caffee, M. W. 2003: Timing and style of Late Quaternary glaciation in northeastern Tibet. Geological Society of America Bulletin 115, 1356-1364.

Pigati, J.S., Quade, J., Wilson, J., Jull, A.J.T., \& Lifton, N.A., 2007: Development of lowbackground vacuum extraction and graphitization systems for $14 \mathrm{C}$ dating of old (40-60 ka) samples. Quaternary International 166, 4-14.

Poolton, N. R. J., Ozanyan, K. B., Wallinga, J., Murray, A. S. \& Bøtter-Jensen, L. 2002: Electrons in feldspar II: a consideration of the influence of conduction band-tail states on luminescence processes. Physics and Chemistry of Minerals 29, 217-225.

Prescott, J. R. \& Hutton, J. T. 1994: Cosmic ray contributions to dose rates for luminescence and ESR dating: Large depths and long-term time variations. Radiation Measurements 23, 497-500.

Qiang, M., Chen, F., Song, L., Liu, X., Li, M. \& Wang, Q. 2013: Late Quaternary aeolian activity in Gonghe Basin, northeastern Qinghai-Tibetan Plateau, China. Quaternary Research 79, 403-412.

Qiang, M., Jin, Y., Liu, X., Song, L., Li, H., Li, F. \& Chen, F. 2016: Late Pleistocene and Holocene aeolian sedimentation in Gonghe Basin, northeastern

Qinghai-Tibetan Plateau: Variability, processes, and climatic implications. Quaternary Science Reviews 132, 57-73.

Qiu, J. 2008: China: the third pole. Nature News 454, 393-396.

Roberts, H. M. 2012: Testing Post-IR IRSL protocols for minimising fading in feldspars, using Alaskan loess with independent chronological control. Radiation Measurements 47, 716-724.

Singh, A., Thomsen, K.J., Sinha, R., Buylaert, J.-P., Carter, A., Mark, D.F., Mason, P.J., Densmore, A.L., Murray, A.S., Jain, M., Paul, D. \& Gupta, S. 2017:

Counter-intuitive influence of Himalayan river morphodynamics on Indus Civilisation urban settlements. Nature Communications 8, 1617. DOI: $10.1038 / s 41467-017-01643-9$.

Sohbati, R., Murray, A. S., Buylaert, J.-P., Ortuño, M., Cunha, P. P. \& Masana, E. 2012: Luminescence dating of Pleistocene alluvial sediments affected by the Alhama 
de Murcia fault (eastern Betics, Spain) - a comparison between OSL, IRSL and post-IRIRSL ages. Boreas 41, 250-262.

Sohbati, R., Borella, J., Murray, A., Quigley, M. \& Buylaert, J.P. 2016: Optical dating of loessic hillslope sediments constrains timing of prehistoric rockfalls, Christchurch, New Zealand. Journal of Quaternary Science 31, 678-690.

Stauch, G. 2015: Geomorphological and palaeoclimate dynamics recorded by the formation of aeolian archives on the Tibetan Plateau. Earth-Science Reviews 150, 393-408.

Stauch, G., IJmker, J., Pötsch, S., Zhao, H., Hilgers, A., Diekmann, B., Dietze, E., Hartmann, K., Opitz, S. \& Wünnemann, B. 2012: Aeolian sediments on the north-eastern Tibetan Plateau. Quaternary Science Reviews 57, 71-84.

Sun, J., Li, S.-H., Muhs, D. R. \& Li, B. 2007: Loess sedimentation in Tibet: provenance, processes, and link with Quaternary glaciations. Quaternary Science Reviews $26,2265-2280$.

Thiel, C., Buylaert, J.-P., Murray, A., Terhorst, B., Hofer, I., Tsukamoto, S. \& Frechen, M. 2011: Luminescence dating of the Stratzing loess profile (Austria) - Testing the potential of an elevated temperature post-IR IRSL protocol. Quaternary International 234, 23-31.

Timar-Gabor, A. \& Wintle, A. G. 2013: On natural and laboratory generated dose response curves for quartz of different grain sizes from Romanian loess. Quaternary Geochronology 18, 34-40.

Thomsen, K. J., Murray, A. S., Jain, M. \& Bøtter-Jensen, L. 2008: Laboratory fading rates of various luminescence signals from feldspar-rich sediment extracts. Radiation Measurements 43, 1474-1486.

Thrasher, I. M., Mauz, B., Chiverrell, R. C. \& Lang, A. 2009: Luminescence dating of glaciofluvial deposits: A review. Earth-Science Reviews 97, 133-146.

Újvári, G., Stevens, T., Molnár, M., Demény, A., Lambert, F., Varga, G., Timothy Jull, A. J., Páll-Gergely, B., Buylaert, J.-P. \& Kovács, J. 2017: Coupled European and Greenland last glacial dust activity driven by North Atlantic climate. Proceedings of the National Academy of Sciences 114, E10632-E10638.

Voelker, A. H. L. 2002: Global distribution of centennial-scale records for Marine Isotope Stage (MIS) 3: a database. Quaternary Science Reviews 21, $1185-1212$.

Wang, X., Yi, S., Lu, H., Vandenberghe, J. \& Han, Z. 2015: Aeolian process and climatic changes in loess records from the northeastern Tibetan Plateau: Response to global temperature forcing since $30 \mathrm{ka}$. Paleoceanography 30, 612-620.

Wintle, A. G. 1973: Anomalous fading of thermo-luminescence in mineral samples. Nature 245, 143-144.

Wintle, A. G. \& Murray, A. S. 2006: A review of quartz optically stimulated luminescence characteristics and their relevance in single-aliquot regeneration dating protocols. Radiation Measurements 41, 369-391.

Yang, S., Fang, X., Shi, Z., Lehmkuhl, F., Song, C., Han, Y. \& Han, W. 2010: Timing and provenance of loess in the Sichuan Basin, southwestern China. Palaeogeography, Palaeoclimatology, Palaeoecology 292, 144-154.

Yi, S., Buylaert, J.P., Murray, A.S., Lu, H., Thiel, C. \& Zeng, L. 2016: A detailed post-IR IRSL dating study of the Niuyangzigou loess site in northeastern China. Boreas 45, 644-657.

Yu, L. \& Lai, Z. 2014: Holocene climate change inferred from stratigraphy and OSL chronology of aeolian sediments in the Qaidam Basin, northeastern Qinghai-Tibetan Plateau. Quaternary Research 81, 488-499. 
Zhang, J., Nottebaum, V., Tsukamoto, S., Lehmkuhl, F. \& Frechen, M. 2015a: Late Pleistocene and Holocene loess sedimentation in central and western Qilian Shan (China) revealed by OSL dating. Quaternary International 372, 120-129.

Zhang, J., Tsukamoto, S., Nottebaum, V., Lehmkuhl, F. \& Frechen, M. 2015b: De plateau and its implications for post-IR IRSL dating of polymineral fine grains. Quaternary Geochronology 30, 147-153.

Zhao, H. \& Li, S.-H. 2005: Internal dose rate to K-feldspar grains from radioactive elements other than potassium. Radiation Measurements 40, 84-93. 


\section{Captions}

Fig. 1. A. An overview of the study area in the Tibetan Plateau, China. B. The location of the HB (Hebei) loess section and the previously published loess sections nearby HB including Suohuduo (SHD) (Lehmkuhl et al. 2014), the T21 and T27 loess sections in Anyemaqen mountains (Owen et al. 2003), Mangla (ML) and Taxiu (TX) loess sections in Gonghe Basin (Qiang et al. 2016), and Hongshuiping (HS) loess section (Wang et al. 2015) and Tuxiangdao (TXD) loess section (Buylaert et al. 2008) in western loess plateau.

Fig. 2. Sand-sized (63-90 $\mu \mathrm{m})$ quartz grain luminescence characteristics. A.

Dose-response curve for sample 153001 (inset shows the natural stimulation curve). B. Preheat plateau tests of three samples from the top (153001), middle (153013) and bottom (153029) of the section. The dashed lines represents the average $\mathrm{D}_{\mathrm{e}}$ over the 160-280 ${ }^{\circ} \mathrm{C}$ interval for sample 153001 , and over the $160-240{ }^{\circ} \mathrm{C}$ interval for samples 153013 and 153029 . C. Dose recovery preheat plateau tests of the same samples as in (B) Three aliquots were measured at each temperature. Error bars represent one standard error. There are no data points for sample 153001 at 280 and $300{ }^{\circ} \mathrm{C}$ in (B) and (C) and for sample 153029 at $300{ }^{\circ} \mathrm{C}$ in (B) due to the absence of signal after preheating to these temperatures.

Fig. 3. The distribution of dose recovery ratios for quartz. All samples were measured under the preheat temperature of $200{ }^{\circ} \mathrm{C}$ and cutheat temperature of $160{ }^{\circ} \mathrm{C}$.

Fig. 4. Typical dose response and stimulation (inset) curves for $\operatorname{IR}_{50}$ and $\operatorname{pIRIR}_{170}$ signals from sample 153013.

Fig. 5. A. Preheat plateau of $\mathrm{IR}_{50}$ from K-feldspar samples. B. Preheat plateau of pIRIR signals from K-feldspar samples. C. Residual doses of $\mathrm{IR}_{50}$ signals measured after $4 \mathrm{~h}$ exposure in a Hönle SOL2 solar simulator. D. Residual doses of pIRIR signals measured after $4 \mathrm{~h}$ exposure in a Hönle SOL2 solar simulator. E. Fading rates (g-value) of $\mathrm{IR}_{50}$ signals from sample 153013. F. Fading rates (g-value) of pIRIR signals from sample 153013 . G. Dose recovery ratios for $\mathrm{IR}_{50}$ signals. H. Dose recovery ratios for pIRIR signals. Open symbols indicate the $\mathrm{IR}_{50}$ signal and filled symbols represent the data of the pIRIR signal. Each data point is the mean of three aliquots. Error bars represent the standard error. 
Fig. 6. Bleaching characteristics of sample 153003. A. Sensitivity-corrected blue-stimulated OSL from quartz, and $\mathrm{IR}_{50}$ and $\mathrm{pIRIR}_{170}$ from K-feldspar plotted against bleaching time in a Hönle SOL2 solar simulator. Each data point represents an average of three aliquots. B. Residual dose with solar bleaching time. Each data point represents an average of three aliquots. C. pIRIR 170 versus $\operatorname{IR}_{50} \mathrm{D}_{e}$ for all the samples. The error bars represent one standard error.

Fig. 7. A. Comparison of K-feldspar uncorrected and corrected $\mathrm{IR}_{50}$ ages with quartz OSL ages. B. Comparison between quartz OSL and K-feldspar pIRIR ${ }_{170}$ ages. Note that pIRIR170 ages have not been corrected for observed fading (g-values $<1 \% / \mathrm{dec}$.) as discussed in the text.

Fig. 8. A. Luminescence and ${ }^{14} \mathrm{C}$ ages as a function of depth for the Hebei section. Error bars represent one standard error (random component only; i.e. counting statistics, instrument reproducibility). Bayesian fit of the luminescence data below the hiatus is given in blue ( $1 \sigma$ error envelope in green) with a depth resolution of $5 \mathrm{~cm}$. B. Calculated MAR values for the Hebei section (red) as a function of luminescence age. Original MAR data for the Xifeng (central CLP; Stevens et al. 2016) and calculated MAR data based on Bayesian age-depth model (see Fig. S1). Three-point continuous smoothing has been applied to all Bayesian MAR data.

Fig. 9. Kernel density estimation of 233 loess-palaeosol ages from 59 sites on the NE Tibetan Plateau (blue curve; kernel bandwidth =1). The black solid curve represents the average loess deposition flux of the CLP (An et al. 1991). Vertical dashed lines show MIS boundaries.

Table 1. Summary of sample codes, depths, radionuclide concentrations and dose rates calculated for quartz and K-feldspar. Data in italics and sample codes with asterisk were measured by ICP-MS and converted into $\mathrm{Bq} \mathrm{kg}^{-1}$.

Table 2. Outline of dose measurement protocols used in this study. A. Quartz OSL protocol after (Murray \& Wintle 2003). B. Post-IR IRSL protocol modified from Thiel et al. (2011) and Buylaert et al. (2012). For the 'natural' sample, $\mathrm{i}=0$. The 
whole sequence is repeated for several regenerative doses including a zero dose and a repeat dose.

Table 3. Summary of quartz OSL and K-feldspar $\mathrm{IR}_{50}$ and $\mathrm{pIRIR}_{170}$ equivalent doses and ages. A fading rate of $\sim 2.58 \%$ /decade as obtained from sample 153013 is used to calculate the corrected $\mathrm{IR}_{50}$ ages for all the samples. Uncertainties on individual quartz and feldspar ages contain both random and systematic components. Ages (and random errors) in bold have been used for Bayesian modelling in Fig. 8.

Supporting Information

Fig. S1. Bayesian fit of the luminescence ages for the Xifeng section published in Stevens et al. (2016). Error bars represent one standard error (random component only). Modelled data are shown in blue ( $1 \sigma$ error envelope in green) with a depth resolution of $5 \mathrm{~cm}$. 


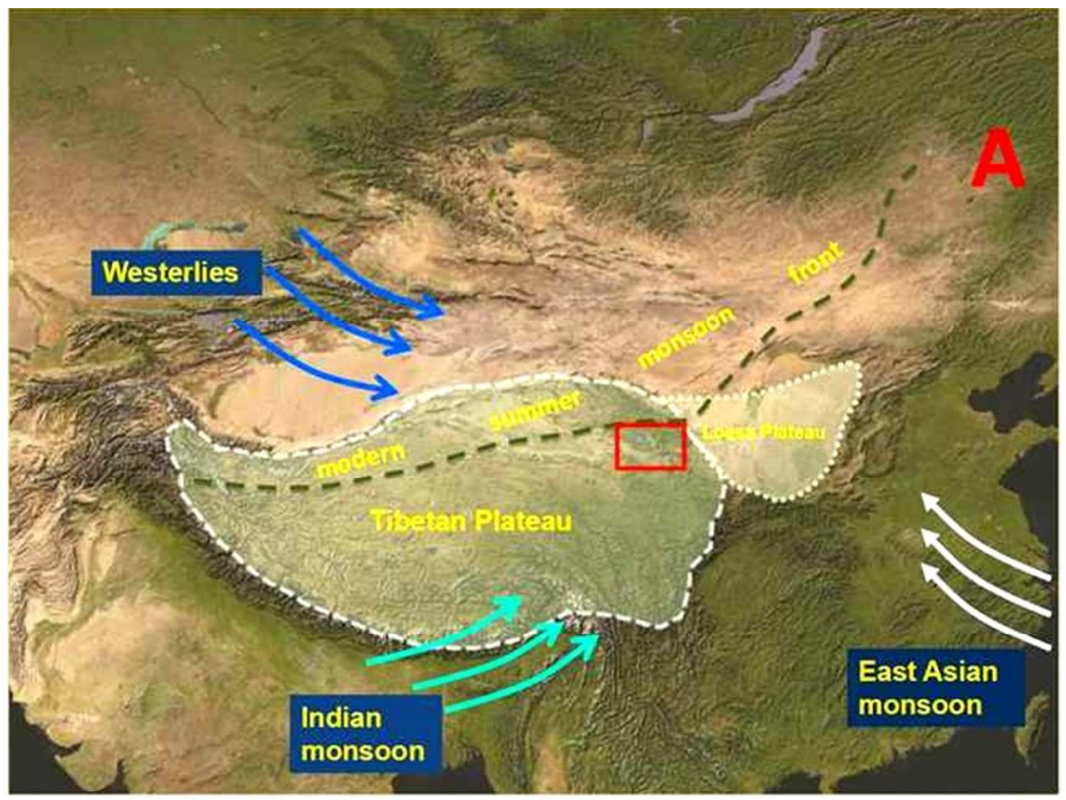

$100^{\circ} 30^{\circ} 48^{\circ} \mathrm{E}$

$101^{\circ} 30^{\circ} 47^{\prime \prime} \mathrm{E} \quad 102^{*} 30^{\circ} 47^{\prime \prime} \mathrm{E}$ $103^{\circ} 30^{\prime} 18^{\circ} \mathrm{E}$

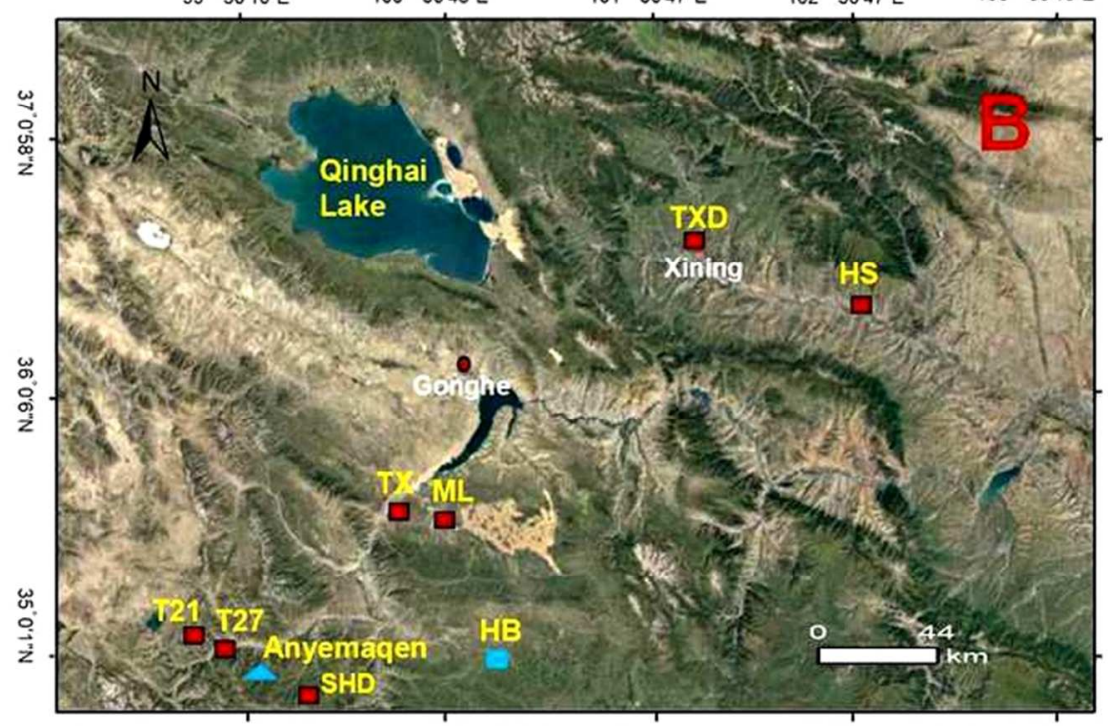

Fig. 1.

$147 \times 203 \mathrm{~mm}(120 \times 120$ DPI $)$ 

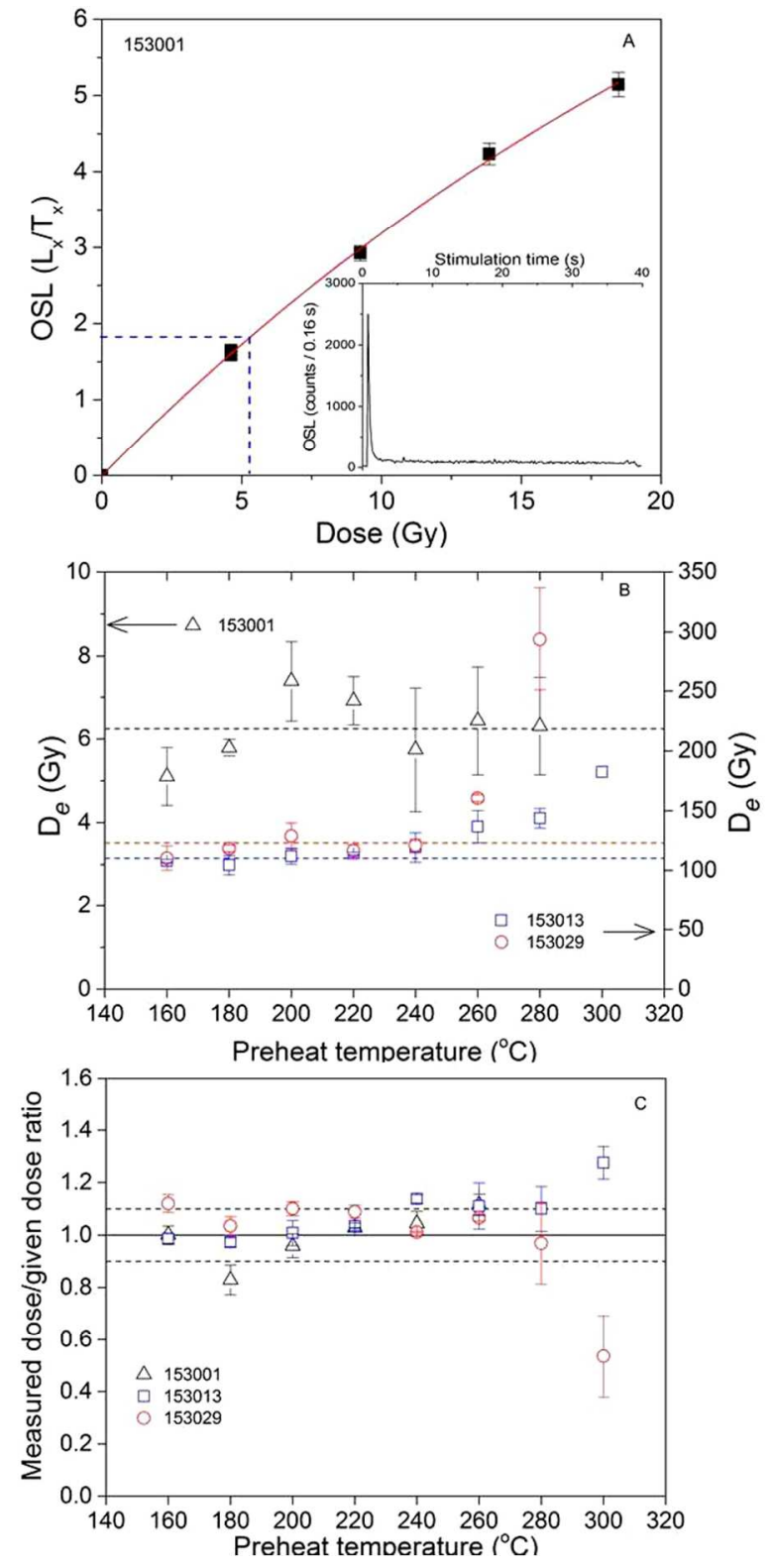

Fig. 2.

$135 \times 276 \mathrm{~mm}(120 \times 120$ DPI $)$ 


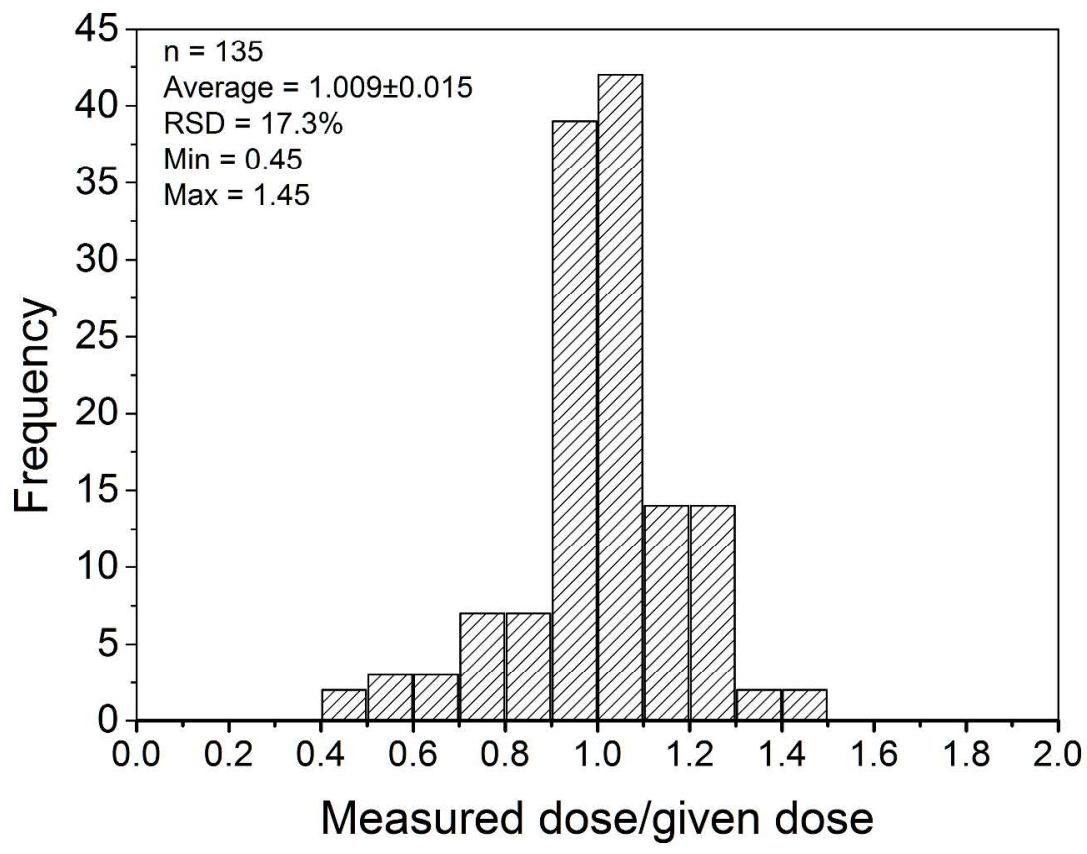

Fig. 3.

$279 \times 215 \mathrm{~mm}(300 \times 300$ DPI $)$ 


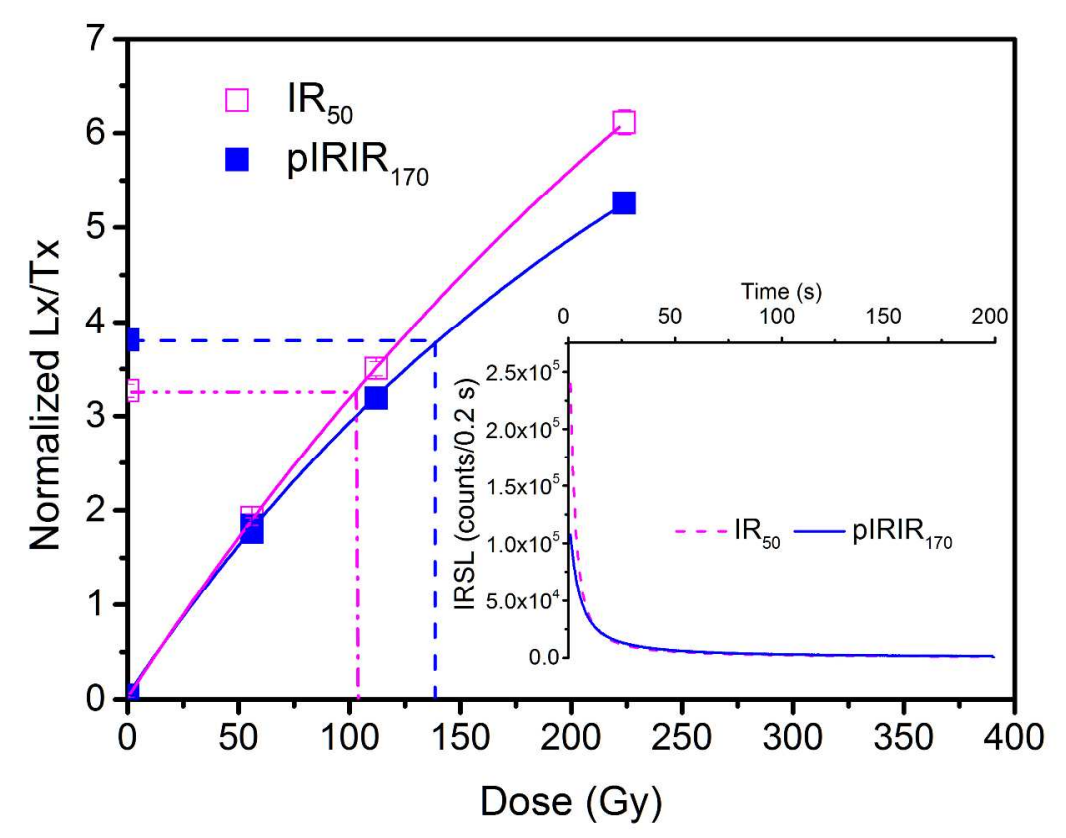

Fig. 4.

$296 \times 209 \mathrm{~mm}$ ( $300 \times 300$ DPI) 


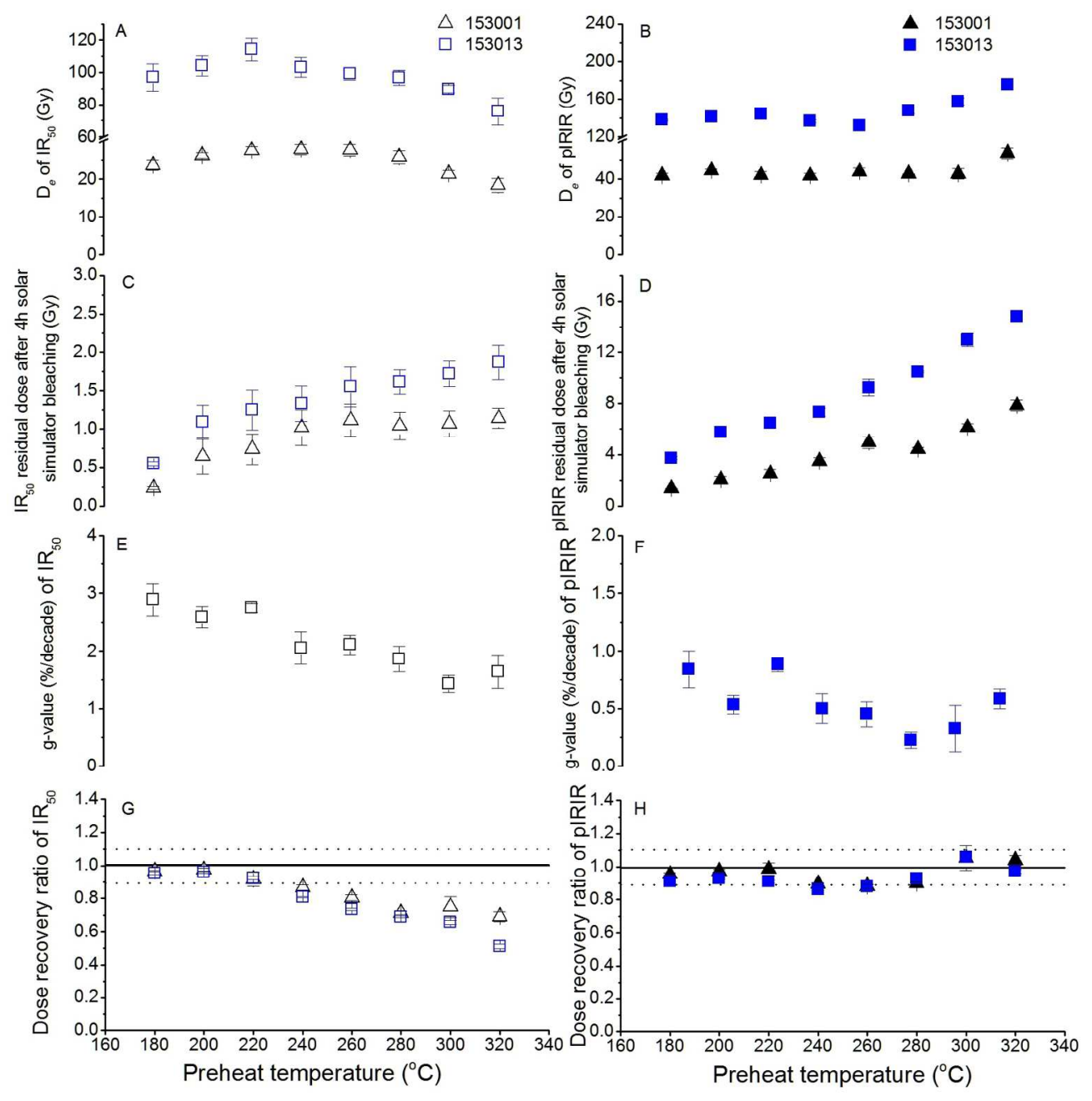

Fig. 5.

$394 \times 399 \mathrm{~mm}(120 \times 120$ DPI $)$ 

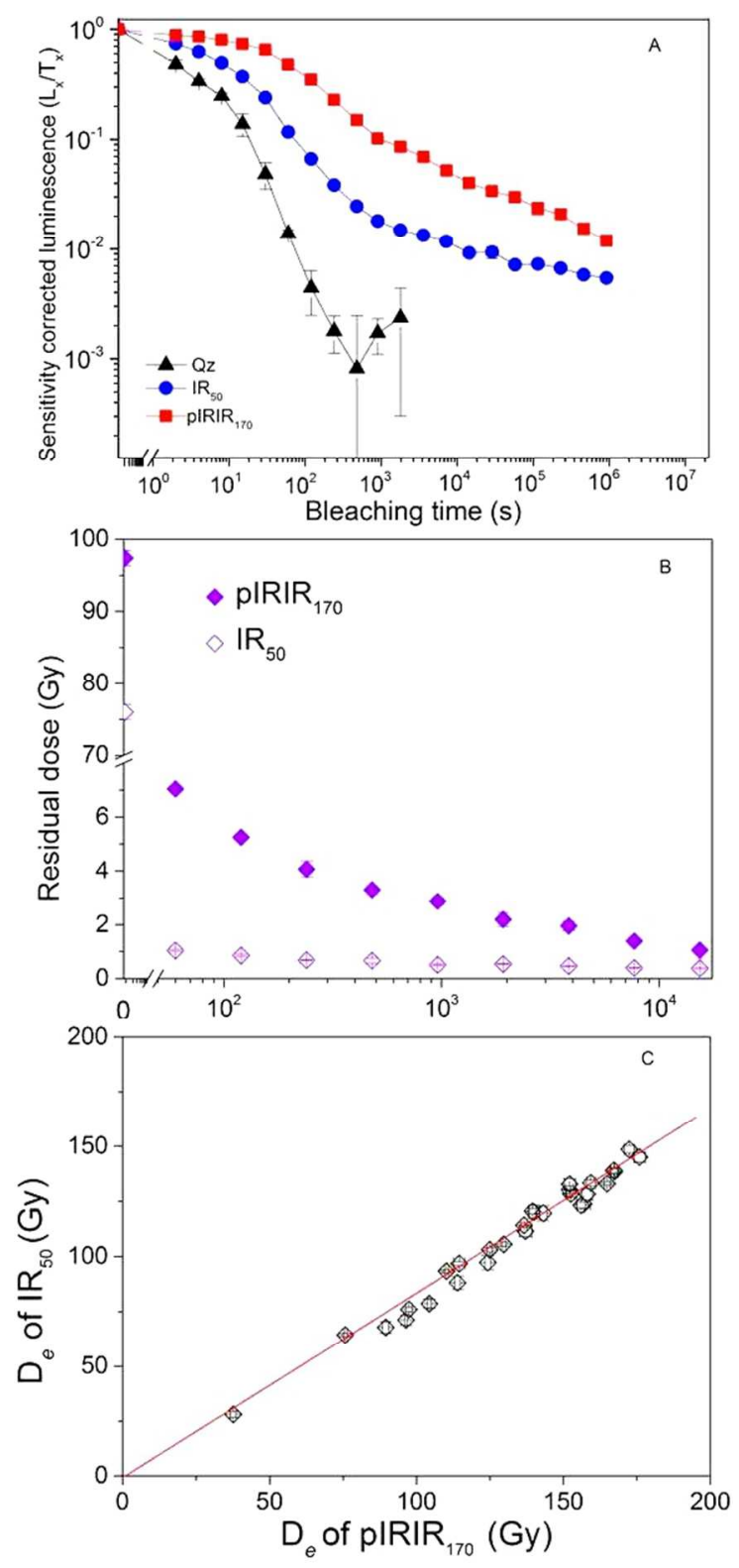

Fig. 6 .

$121 \times 262 \mathrm{~mm}(120 \times 120$ DPI $)$ 

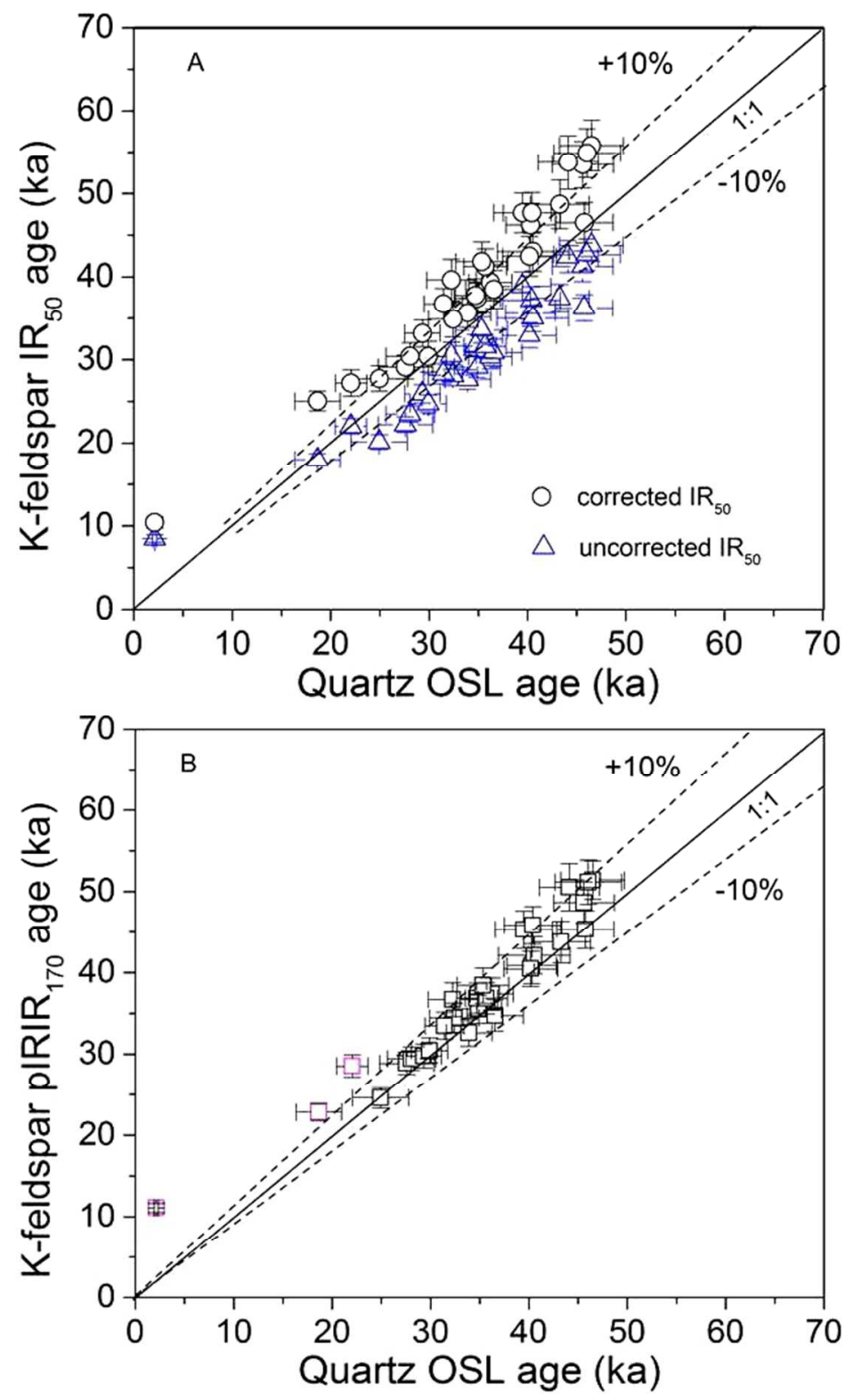

Fig. 7.

$135 \times 225 \mathrm{~mm}(120 \times 120 \mathrm{DPI})$ 


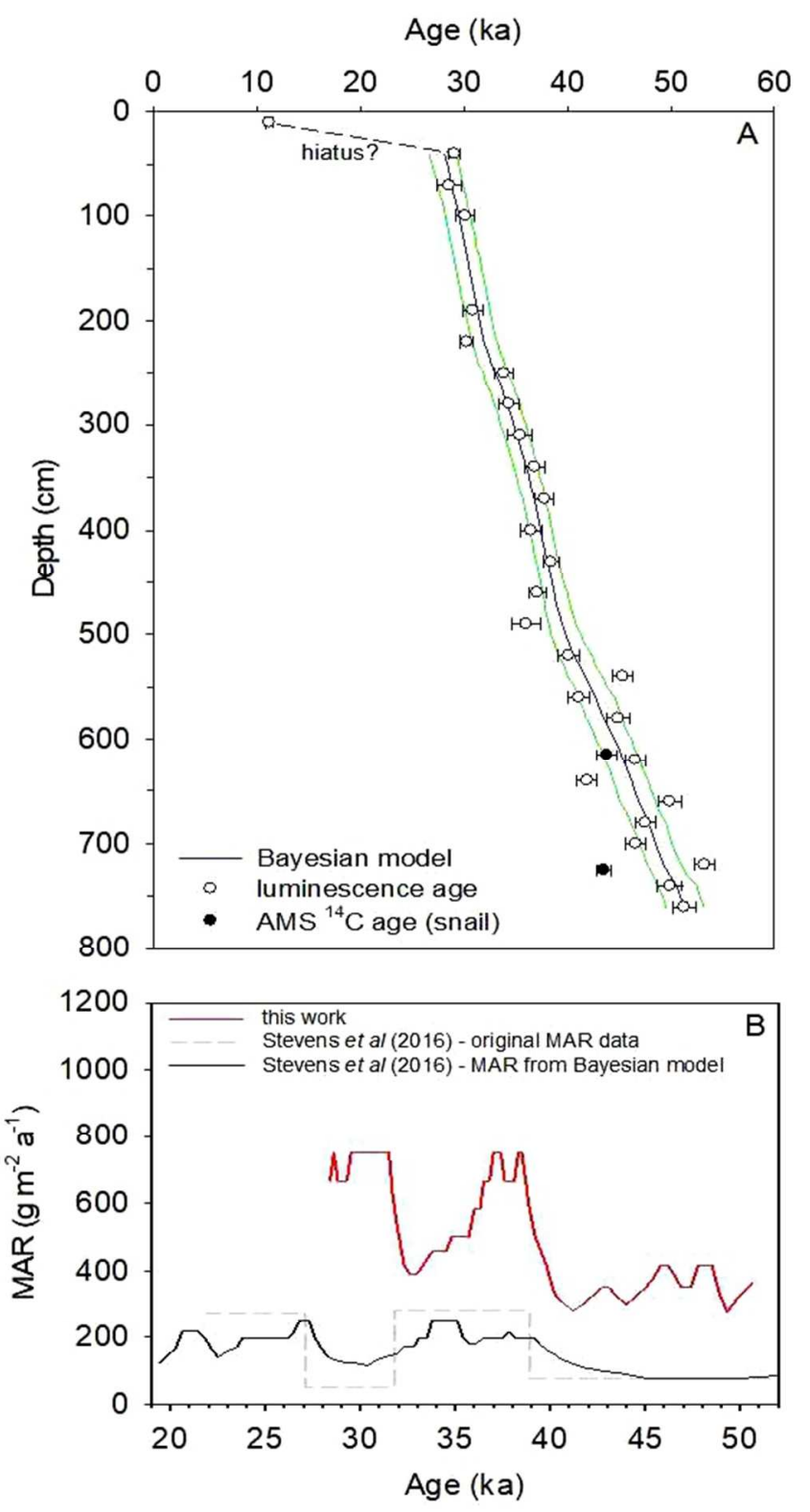

Fig. 8.

$117 \times 220 \mathrm{~mm}(120 \times 120 \mathrm{DPI})$ 


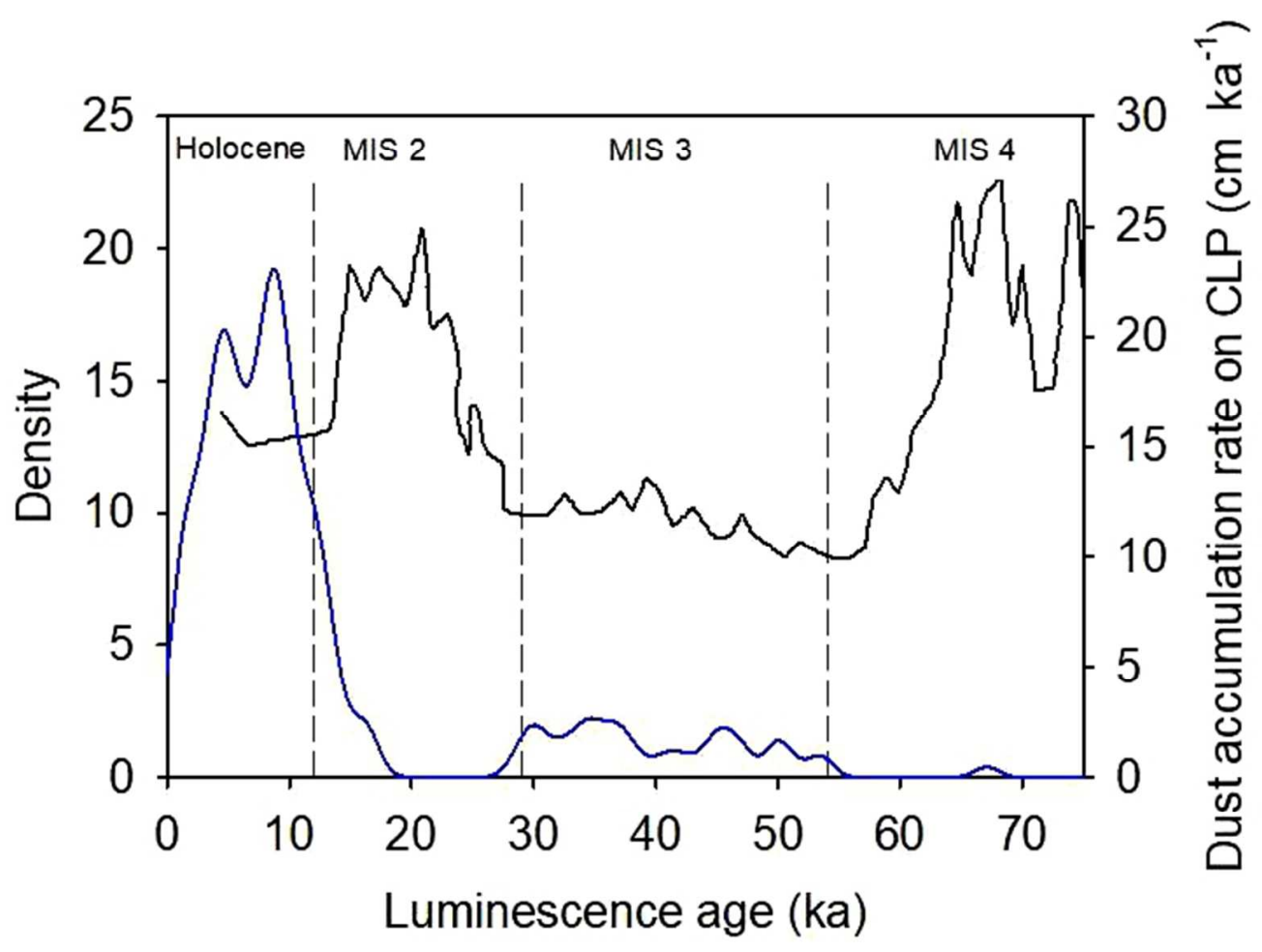

Fig. 9.

$152 \times 112 \mathrm{~mm}(120 \times 120$ DPI $)$ 


\begin{tabular}{|c|c|c|c|c|c|c|c|}
\hline $\begin{array}{l}\text { Sample } \\
\text { code }\end{array}$ & $\begin{array}{l}\text { Depth } \\
\text { (m) }\end{array}$ & $\begin{array}{c}{ }^{238} \mathrm{U} \\
\left(\mathrm{Bq} \mathrm{kg}{ }^{-1}\right)\end{array}$ & $\begin{array}{c}{ }^{226} \mathrm{Ra} \\
\left(\mathrm{Bq} \mathrm{kg}^{-1}\right)\end{array}$ & $\begin{array}{c}{ }^{232} \mathrm{Th} \\
\left(\mathrm{Bq} \mathrm{kg}^{-1}\right)\end{array}$ & $\begin{array}{c}{ }^{40} \mathrm{~K} \\
\left(\mathrm{~Bq} \mathrm{~kg}{ }^{-1}\right)\end{array}$ & $\begin{array}{l}\text { Quartz dose } \\
\text { rate }\left(\mathrm{Gy} \mathrm{ka}^{-1}\right)\end{array}$ & $\begin{array}{c}\text { K-feldspar dose } \\
\text { rate }\left(\mathrm{Gy} \mathrm{ka}^{-1}\right)\end{array}$ \\
\hline 153001 & 10 & $29.2 \pm 16.5$ & $33.7 \pm 1.2$ & $42.1 \pm 1.3$ & $459 \pm 17$ & $2.99 \pm 0.12$ & $3.37 \pm 0.13$ \\
\hline 153002 & 40 & $36.2 \pm 20.0$ & $30.6 \pm 1.1$ & $42.9 \pm 1.5$ & $479 \pm 20$ & $2.93 \pm 0.13$ & $3.32 \pm 0.13$ \\
\hline 153003 & 70 & $32.1 \pm 15.3$ & $34.4 \pm 1.1$ & $41.9 \pm 1.1$ & $488 \pm 19$ & $2.96 \pm 0.13$ & $3.34 \pm 0.14$ \\
\hline $153004^{*}$ & 100 & $30.6 \pm 3.7$ & - & $41.2 \pm 2.8$ & $541 \pm 13$ & $3.02 \pm 0.13$ & $3.40 \pm 0.14$ \\
\hline 153005 & 130 & $34.2 \pm 12.5$ & $32.1 \pm 1.0$ & $40.8 \pm 0.9$ & $494 \pm 16$ & $3.12 \pm 0.13$ & $3.50 \pm 0.14$ \\
\hline $153006^{*}$ & 160 & $32.6 \pm 3.7$ & - & $41.0 \pm 2.8$ & $577 \pm 13$ & $3.12 \pm 0.14$ & $3.50 \pm 0.15$ \\
\hline $153007^{*}$ & 190 & $36.8 \pm 3.7$ & - & $40.7 \pm 2.8$ & $572 \pm 13$ & $3.15 \pm 0.16$ & $3.53 \pm 0.15$ \\
\hline 153008 & 220 & $34.5 \pm 19.5$ & $37.3 \pm 1.5$ & $49.4 \pm 1.4$ & $587 \pm 25$ & $3.33 \pm 0.15$ & $3.72 \pm 0.16$ \\
\hline 153009 & 250 & $43.7 \pm 17.3$ & $33.9 \pm 1.3$ & $42.1 \pm 1.4$ & $552 \pm 20$ & $3.05 \pm 0.13$ & $3.44 \pm 0.14$ \\
\hline 153010 & 280 & $36.3 \pm 22.2$ & $36.7 \pm 1.7$ & $44.0 \pm 1.5$ & $577 \pm 28$ & $3.19 \pm 0.15$ & $3.57 \pm 0.16$ \\
\hline $153011^{*}$ & 310 & $33.2 \pm 3.7$ & - & $42.5 \pm 2.8$ & $610 \pm 13$ & $3.20 \pm 0.14$ & $3.58 \pm 0.15$ \\
\hline 153012 & 340 & $48.8 \pm 16.8$ & $36.8 \pm 1.3$ & $47.2 \pm 1.2$ & $563 \pm 22$ & $3.19 \pm 0.14$ & $3.57 \pm 0.15$ \\
\hline 153013 & 370 & $43.3 \pm 21.1$ & $38.4 \pm 1.6$ & $46.6 \pm 1.5$ & $577 \pm 27$ & $3.23 \pm 0.15$ & $3.62 \pm 0.16$ \\
\hline 153014 & 400 & $79.8 \pm 28.8$ & $38.7 \pm 2.1$ & $49.4 \pm 2.0$ & $641 \pm 37$ & $3.45 \pm 0.17$ & $3.84 \pm 0.18$ \\
\hline $153015^{*}$ & 430 & $35.0 \pm 3.7$ & . & $43.8 \pm 2.8$ & $595 \pm 13$ & $3.17 \pm 0.16$ & $3.56 \pm 0.15$ \\
\hline 153016 & 460 & $35.7 \pm 21.1$ & $39.0 \pm 1.6$ & $51.1 \pm 1.5$ & $608 \pm 28$ & $3.38 \pm 0.16$ & $3.76 \pm 0.16$ \\
\hline 153017 & 490 & $42.0 \pm 30.3$ & $41.8 \pm 2.2$ & $51.5 \pm 2.0$ & $631 \pm 36$ & $3.48 \pm 0.17$ & $3.87 \pm 0.18$ \\
\hline 153018 & 520 & $75.9 \pm 31.9$ & $41.3 \pm 2.3$ & $51.7 \pm 2.5$ & $611 \pm 33$ & $3.42 \pm 0.17$ & $3.80 \pm 0.17$ \\
\hline 153019 & 540 & $15.1 \pm 23.0$ & $36.8 \pm 1.6$ & $44.3 \pm 1.8$ & $538 \pm 24$ & $3.02 \pm 0.14$ & $3.41 \pm 0.15$ \\
\hline 153020 & 560 & $37.6 \pm 25.4$ & $39.2 \pm 1.9$ & $48.9 \pm 1.7$ & $605 \pm 31$ & $3.32 \pm 0.16$ & $3.70 \pm 0.17$ \\
\hline 153021 & 580 & $52.5 \pm 21.9$ & $36.0 \pm 1.6$ & $47.4 \pm 1.5$ & $558 \pm 28$ & $3.11 \pm 0.15$ & $3.49 \pm 0.15$ \\
\hline 153022 & 620 & $52.2 \pm 19.9$ & $36.7 \pm 1.5$ & $41.9 \pm 1.6$ & $539 \pm 22$ & $2.97 \pm 0.14$ & $3.35 \pm 0.15$ \\
\hline 153023 & 640 & $31.6 \pm 20.6$ & $41.3 \pm 1.5$ & $50.0 \pm 1.4$ & $619 \pm 26$ & $3.39 \pm 0.16$ & $3.77 \pm 0.16$ \\
\hline 153024 & 660 & $46.6 \pm 20.7$ & $33.4 \pm 1.5$ & $39.4 \pm 1.6$ & $517 \pm 23$ & $2.81 \pm 0.13$ & $3.19 \pm 0.14$ \\
\hline 153025 & 680 & $35.8 \pm 18.0$ & $34.8 \pm 1.4$ & $44.0 \pm 1.3$ & $601 \pm 24$ & $3.14 \pm 0.14$ & $3.52 \pm 0.15$ \\
\hline 153026 & 700 & $44.9 \pm 19.0$ & $37.4 \pm 1.4$ & $48.0 \pm 1.4$ & $571 \pm 25$ & $3.15 \pm 0.15$ & $3.54 \pm 0.15$ \\
\hline 153027 & 720 & $28.6 \pm 15.3$ & $32.7 \pm 1.1$ & $41.9 \pm 1.2$ & $491 \pm 16$ & $2.76 \pm 0.12$ & $3.14 \pm 0.13$ \\
\hline 153028 & 740 & $14.4 \pm 29.7$ & $33.0 \pm 1.9$ & $43.4 \pm 2.1$ & $593 \pm 27$ & $3.07 \pm 0.15$ & $3.45 \pm 0.15$ \\
\hline 153029 & 760 & $28.4 \pm 22.8$ & $33.4 \pm 1.5$ & $41.5 \pm 1.6$ & $594 \pm 22$ & $3.04 \pm 0.14$ & $3.43 \pm 0.15$ \\
\hline
\end{tabular}




\begin{tabular}{|c|c|c|c|c|}
\hline Step & Quartz OSL & Observed & K-feldspar pIRIR & Observed \\
\hline$\overline{1}$ & $\begin{array}{l}\text { Regenerative dose, } R_{i}(i=0,1,2, \\
3 \ldots)\end{array}$ & & $\begin{array}{l}\text { Regenerative dose, } \quad \mathrm{R}_{\mathrm{i}}(\mathrm{i}=0,1,2, \\
3 \ldots)\end{array}$ & \\
\hline 2 & Preheat $\left(200^{\circ} \mathrm{C}, 10 \mathrm{~s}\right)$ & & Preheat $\left(200^{\circ} \mathrm{C}, 60 \mathrm{~s}\right)$ & \\
\hline 3 & & & IRSL stimulation $\left(50^{\circ} \mathrm{C}, 200 \mathrm{~s}\right)$ & $\mathrm{L}_{\mathrm{x}, \mathrm{IR} 50}$ \\
\hline 4 & $\operatorname{OSL}\left(125^{\circ} \mathrm{C}, 40 \mathrm{~s}\right)$ & $\mathrm{L}_{\mathrm{x}}$ & IRSL stimulation $\left(170^{\circ} \mathrm{C}, 200 \mathrm{~s}\right)$ & $\mathrm{L}_{\mathrm{x}, \mathrm{pIRIR} 170}$ \\
\hline 5 & Test dose & & Test dose & \\
\hline 6 & Cut-heat $\left(160^{\circ} \mathrm{C}\right)$ & & Preheat $\left(200^{\circ} \mathrm{C}, 60 \mathrm{~s}\right)$ & \\
\hline 7 & & & IRSL stimulation $\left(50^{\circ} \mathrm{C}, 200 \mathrm{~s}\right)$ & $\mathrm{T}_{\mathrm{x}, \mathrm{IR} 50}$ \\
\hline 8 & $\operatorname{OSL}\left(125^{\circ} \mathrm{C}, 40 \mathrm{~s}\right)$ & $\mathrm{T}_{\mathrm{x}}$ & IRSL stimulation $\left(170^{\circ} \mathrm{C}, 200 \mathrm{~s}\right)$ & $\mathrm{T}_{\mathrm{x}, \mathrm{pIRIR} 170}$ \\
\hline 9 & OSL $\left(280^{\circ} \mathrm{C}, 40 \mathrm{~s}\right)$ & & IRSL stimulation $\left(205^{\circ} \mathrm{C}, 200 \mathrm{~s}\right)$ & \\
\hline 10 & Return to step 1 & & Return to step 1 & \\
\hline
\end{tabular}




\begin{tabular}{|c|c|c|c|c|c|c|c|c|c|c|c|c|c|}
\hline \multirow{2}{*}{$\begin{array}{c}\text { Sample } \\
\text { no. }\end{array}$} & \multirow{2}{*}{$\begin{array}{l}\text { Sample } \\
\text { name }\end{array}$} & \multirow{2}{*}{$\begin{array}{l}\text { Depth } \\
(\mathrm{cm})\end{array}$} & \multicolumn{3}{|c|}{ Quartz } & \multicolumn{5}{|c|}{ K-feldspar } & \multirow[b]{2}{*}{$\begin{array}{l}\text { Average } \\
\text { age (ka) }\end{array}$} & \multirow[b]{2}{*}{$\begin{array}{l}\text { Random } \\
\text { error (ka) }\end{array}$} & \multirow[b]{2}{*}{$\begin{array}{l}\text { Total } \\
\text { error }(\mathrm{ka})\end{array}$} \\
\hline & & & $\mathrm{D}_{e}(\mathrm{~Gy})$ & Age (ka) & (n) & $\begin{array}{c}\mathrm{D}_{e}(\mathrm{~Gy}) \\
\mathrm{IR}_{50}\end{array}$ & $\begin{array}{l}\mathrm{D}_{e}(\mathrm{~Gy}) \\
\mathrm{pIRIR}_{170}\end{array}$ & (n) & $\begin{array}{l}\text { Corrected } \\
\mathrm{IR}_{50} \text { age } \\
(\mathrm{ka})\end{array}$ & $\begin{array}{l}\text { Uncorrected } \\
\text { pIRIR }_{170} \text { age } \\
\text { (ka) }\end{array}$ & & & \\
\hline 153001 & HB01 & 10 & $6.6 \pm 0.5$ & $2.2 \pm 0.2$ & 23 & $29.5 \pm 1$ & $37.6 \pm 0.9$ & 12 & $10.7 \pm 0.7$ & $11.2 \pm 0.6$ & - & - & - \\
\hline 153002 & HB02 & 40 & $65.3 \pm 3.3$ & $22.3 \pm 1.6$ & 22 & $74.8 \pm 0.8$ & $96.4 \pm 0.5$ & 12 & $27.4 \pm 1.6$ & $29.1 \pm 1.5$ & - & 0.5 & - \\
\hline 153003 & HB03 & 70 & $82.7 \pm 6.4$ & $28.0 \pm 2.6$ & 16 & $76 \pm 1$ & $97.4 \pm 1$ & 12 & $29.3 \pm 1.4$ & $29.1 \pm 1.4$ & 28.6 & 1.1 & 1.8 \\
\hline 153004 & HB04 & 100 & $89.2 \pm 4.8$ & $29.6 \pm 2.2$ & 20 & $81.7 \pm 0.8$ & $104.4 \pm 0.6$ & 12 & $30.6 \pm 1.6$ & $30.7 \pm 1.5$ & 30.1 & 0.9 & 1.8 \\
\hline 153005 & HB05 & 130 & $54.1 \pm 6.2$ & $17.4 \pm 2.2$ & 15 & $64.4 \pm 0.7$ & $75.7 \pm 0.6$ & 12 & $25.2 \pm 1.2$ & $21.6 \pm 1.1$ & - & - & - \\
\hline 153006 & HB06 & 160 & $70.0 \pm 5.1$ & $22.5 \pm 2.0$ & 17 & $72 \pm 1$ & $89.5 \pm 1$ & 12 & $24.9 \pm 1.5$ & $25.6 \pm 1.3$ & - & - & - \\
\hline 153007 & HB07 & 190 & $96.1 \pm 5.3$ & $30.5 \pm 2.3$ & 17 & $93.4 \pm 0.7$ & $110.2 \pm 0.7$ & 12 & $33.3 \pm 1.6$ & $31.2 \pm 1.6$ & 30.8 & 0.9 & 1.8 \\
\hline 153008 & HB08 & 220 & $99.5 \pm 3.2$ & $29.9 \pm 1.9$ & 17 & $93.6 \pm 0.6$ & $113.9 \pm 0.9$ & 12 & $30.5 \pm 1.8$ & $30.7 \pm 1.6$ & 30.3 & 0.6 & 1.6 \\
\hline 153009 & HB09 & 250 & $105.1 \pm 4.8$ & $34.4 \pm 2.4$ & 12 & $96.8 \pm 1$ & $114.6 \pm 1.9$ & 12 & $35.8 \pm 1.7$ & $33.3 \pm 1.7$ & 33.9 & 0.9 & 1.9 \\
\hline 153010 & HB10 & 280 & $108.1 \pm 5.5$ & $33.9 \pm 2.5$ & 20 & $102.2 \pm 1$ & $124.3 \pm 0.9$ & 12 & $35.0 \pm 2.1$ & $34.8 \pm 1.8$ & 34.3 & 1.0 & 2.0 \\
\hline 153011 & HB11 & 310 & $115.0 \pm 6.7$ & $36.0 \pm 2.8$ & 19 & $103.1 \pm 1$ & $124.9 \pm 0.9$ & 12 & $36.9 \pm 1.9$ & $34.9 \pm 1.7$ & 35.4 & 1.2 & 2.1 \\
\hline 153012 & HB12 & 340 & $118.9 \pm 5.5$ & $37.3 \pm 2.6$ & 16 & $105.6 \pm 0.9$ & $129.7 \pm 0.8$ & 12 & $37.6 \pm 1.8$ & $36.3 \pm 1.8$ & 36.8 & 1.0 & 2.1 \\
\hline 153013 & HB13 & 370 & $121.6 \pm 3.7$ & $37.6 \pm 2.4$ & 27 & $111.5 \pm 2.5$ & $137.1 \pm 2.1$ & 12 & $39.5 \pm 2.2$ & $37.9 \pm 2.0$ & 37.8 & 0.9 & 2.1 \\
\hline 153014 & HB14 & 400 & $138.9 \pm 7.0$ & $40.2 \pm 3.1$ & 21 & $120.2 \pm 3$ & $140 \pm 1.7$ & 12 & $38.6 \pm 2.3$ & $36.5 \pm 2.0$ & - & 1.0 & - \\
\hline 153015 & HB15 & 430 & $114.6 \pm 2.6$ & $36.1 \pm 2.1$ & 24 & $114.2 \pm 0.9$ & $136.6 \pm 0.9$ & 12 & $37.9 \pm 2$ & $38.4 \pm 1.9$ & - & 0.7 & - \\
\hline 153016 & HB16 & 460 & $120.2 \pm 3.3$ & $35.6 \pm 2.2$ & 11 & $120.6 \pm 1.3$ & $139.5 \pm 1.3$ & 12 & $41.4 \pm 2.1$ & $37.1 \pm 1.9$ & - & 0.8 & - \\
\hline
\end{tabular}




\begin{tabular}{|c|c|c|c|c|c|c|c|c|c|c|c|c|c|}
\hline 153017 & HB17 & 490 & $112.5 \pm 5.7$ & $32.3 \pm 2.5$ & 11 & $119.6 \pm 3.4$ & $139.2 \pm 4.1$ & 11 & $39.8 \pm 2.5$ & $36.0 \pm 2.2$ & - & 1.4 & - \\
\hline 153018 & HB18 & 520 & $125.6 \pm 5.7$ & $36.8 \pm 2.7$ & 16 & $129.4 \pm 1.7$ & $152.5 \pm 1.4$ & 12 & $41.9 \pm 2.4$ & $40.1 \pm 2.2$ & - & 1.0 & - \\
\hline 153019 & HB19 & 540 & $132.4 \pm 3.8$ & $43.8 \pm 2.7$ & 13 & $129.2 \pm 1.6$ & $154.4 \pm 1.3$ & 12 & $48.8 \pm 2.9$ & $45.3 \pm 2.3$ & - & 1.0 & - \\
\hline 153020 & HB20 & 560 & $133.4 \pm 3.5$ & $40.2 \pm 2.5$ & 13 & $133.5 \pm 1.8$ & $152.1 \pm 1.9$ & 12 & $46.3 \pm 2.6$ & $41.1 \pm 2.2$ & - & 1.1 & - \\
\hline 153021 & HB21 & 580 & $146.3 \pm 11.1$ & $47.1 \pm 4.4$ & 11 & $123.8 \pm 1.9$ & $156.8 \pm 2.3$ & 12 & $43.2 \pm 2.3$ & $44.9 \pm 2.4$ & - & 1.2 & - \\
\hline 153022 & HB23 & 620 & $138.6 \pm 4.7$ & $46.7 \pm 3.0$ & 15 & $123.1 \pm 1.2$ & $156.1 \pm 1.4$ & 15 & $46.6 \pm 2.4$ & $46.6 \pm 2.4$ & - & 1.0 & - \\
\hline 153023 & HB24 & 640 & $140.4 \pm 5.6$ & $41.4 \pm 2.8$ & 12 & $125.7 \pm 1.9$ & $158.1 \pm 1.8$ & 15 & $42.6 \pm 2.4$ & $41.9 \pm 2.2$ & - & 0.9 & - \\
\hline 153024 & HB25 & 660 & $136.8 \pm 7.9$ & $48.7 \pm 3.9$ & 11 & $133.4 \pm 1.4$ & $159.3 \pm 1.5$ & 12 & $53.6 \pm 2.8$ & $49.9 \pm 2.6$ & - & 1.1 & - \\
\hline 153025 & HB26 & 680 & $138.3 \pm 10.6$ & $44.1 \pm 4.1$ & 11 & $138.6 \pm 1.3$ & $167.4 \pm 1.3$ & 12 & $47.8 \pm 2.4$ & $47.5 \pm 2.4$ & - & 1.0 & - \\
\hline 153026 & HB27 & 700 & $128.6 \pm 6.1$ & $40.8 \pm 3.0$ & 10 & $133.1 \pm 0.8$ & $164.9 \pm 1$ & 12 & $47.8 \pm 2.4$ & $46.6 \pm 2.4$ & - & 1.0 & - \\
\hline 153027 & HB28 & 720 & $142.8 \pm 12.4$ & $51.8 \pm 5.3$ & 11 & $139.1 \pm 1.2$ & $167.2 \pm 1.1$ & 12 & $55.9 \pm 3.1$ & $53.3 \pm 2.6$ & - & 1.0 & - \\
\hline 153028 & HB29 & 740 & $132.2 \pm 4.4$ & $43.1 \pm 2.8$ & 10 & $148.1 \pm 1.6$ & $172.4 \pm 1.7$ & 13 & $53.8 \pm 3.2$ & $49.9 \pm 2.6$ & - & 1.2 & - \\
\hline 153029 & HB30 & 760 & $135.9 \pm 6.6$ & $44.6 \pm 3.3$ & 12 & $147.9 \pm 1.5$ & $175.9 \pm 1.9$ & 12 & $55.0 \pm 3$ & $51.3 \pm 2.6$ & - & 1.1 & - \\
\hline
\end{tabular}




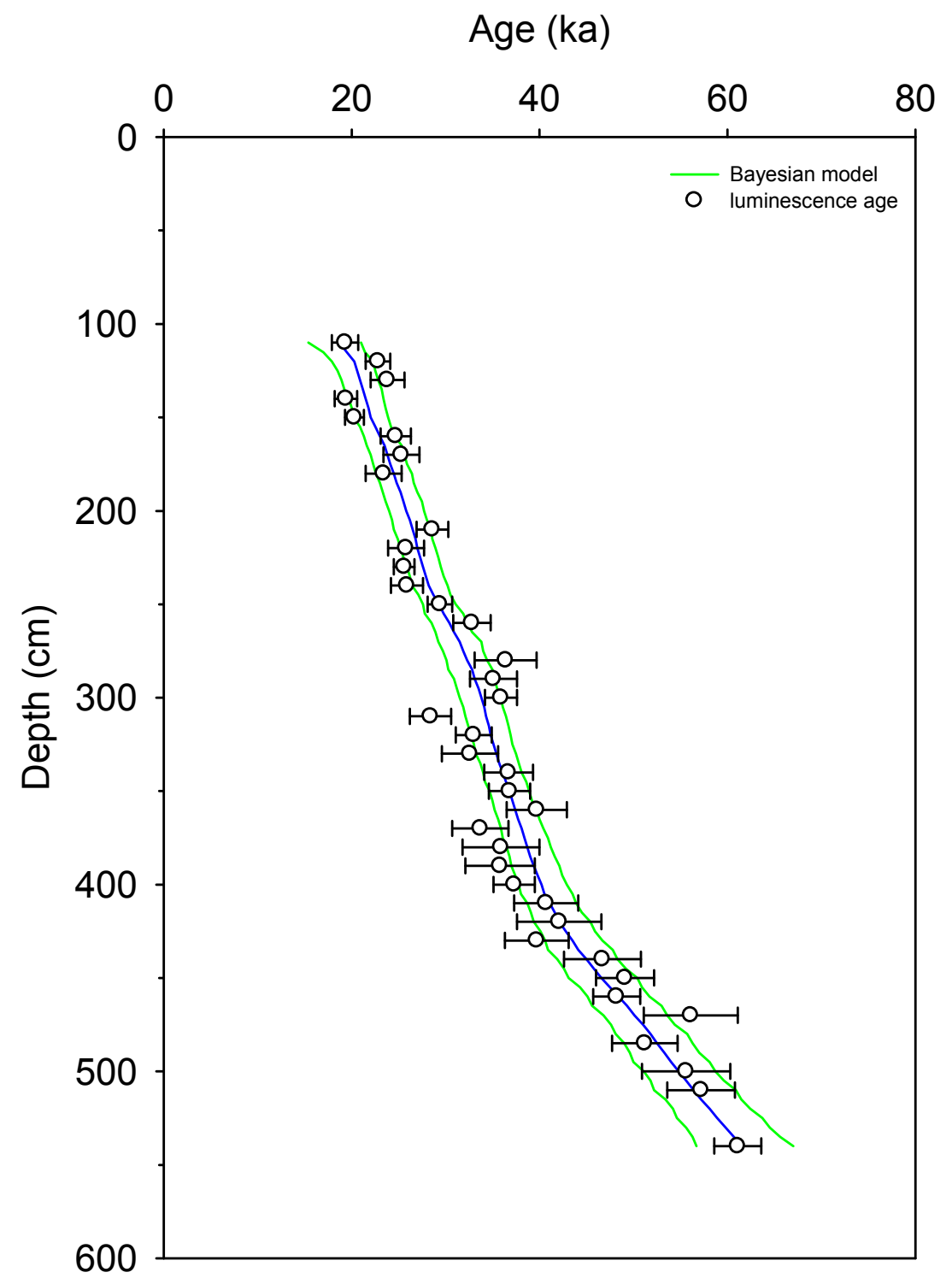

Fig. S1. Bayesian fit of the luminescence ages for the Xifeng section published in Stevens et al. (2016). Error bars represent one standard error (random component only). Modelled data are shown in blue ( $1 \sigma$ error envelope in green) with a depth resolution of $5 \mathrm{~cm}$. 